IZA DP No. 8817

Subsidized Start-Ups out of Unemployment:

A Comparison to Regular Business Start-Ups

Marco Caliendo

Jens Hogenacker

Steffen Künn

Frank Wießner

January 2015 


\title{
Subsidized Start-Ups out of Unemployment: A Comparison to Regular Business Start-Ups
}

\author{
Marco Caliendo \\ University of Potsdam, IZA, DIW Berlin and IAB \\ Jens Hogenacker \\ IZA and University of Potsdam
}

Steffen Künn

IZA

Frank Wießner

$I A B$

Discussion Paper No. 8817
January 2015

IZA

P.O. Box 7240

53072 Bonn

Germany

Phone: +49-228-3894-0

Fax: +49-228-3894-180

E-mail: iza@iza.org

\begin{abstract}
Any opinions expressed here are those of the author(s) and not those of IZA. Research published in this series may include views on policy, but the institute itself takes no institutional policy positions. The IZA research network is committed to the IZA Guiding Principles of Research Integrity.

The Institute for the Study of Labor (IZA) in Bonn is a local and virtual international research center and a place of communication between science, politics and business. IZA is an independent nonprofit organization supported by Deutsche Post Foundation. The center is associated with the University of Bonn and offers a stimulating research environment through its international network, workshops and conferences, data service, project support, research visits and doctoral program. IZA engages in (i) original and internationally competitive research in all fields of labor economics, (ii) development of policy concepts, and (iii) dissemination of research results and concepts to the interested public.
\end{abstract}

IZA Discussion Papers often represent preliminary work and are circulated to encourage discussion. Citation of such a paper should account for its provisional character. A revised version may be available directly from the author. 


\section{ABSTRACT \\ Subsidized Start-Ups out of Unemployment: A Comparison to Regular Business Start-Ups*}

Offering unemployed individuals a subsidy to become self-employed is a widespread active labor market policy strategy. Previous studies have illustrated its high effectiveness to help participants escaping unemployment and improving their labor market prospects compared to other unemployed individuals. However, the examination of start-up subsidies from a business perspective has only received little attention to date. Using a new dataset based on a survey allows us to compare subsidized start-ups out of unemployment with regular business founders, with respect to not only personal characteristics but also business outcomes. The results indicate that previously unemployed entrepreneurs face disadvantages in variables correlated with entrepreneurial ability and access to capital. 19 months after start-up, the subsidized businesses experience higher survival, but lag behind regular business founders in terms of income, business growth and innovation. Moreover, we show that expected deadweight losses related to start-up subsidies occur on a (much) lower scale than usually assumed.

JEL Classification: C14, L26, J68

Keywords: entrepreneurship, start-up subsidies, evaluation, deadweight effects, innovation

Corresponding author:

Marco Caliendo

University of Potsdam

Chair of Empirical Economics

August-Bebel-Str. 89

14482 Potsdam

Germany

E-mail: caliendo@uni-potsdam.de

\footnotetext{
* The authors thank Mirjam van Praag and two anonymous referees for helpful comments and suggestions. We further thank participants at the 2013 IECER in Brescia, the 2013 ESPE conference in Aarhus, the 2013 IZA Summer School and seminars at University of Potsdam and University of Jena for helpful discussions and comments. Financial support of the Institute for Employment Research (IAB) in Nuremberg under the research grant No. 1143 is gratefully acknowledged. We further thank the Chambers of Industry and Commerce, and Chambers of Crafts for their active support in constructing the data. A Supplementary Appendix is available online:

http://ftp.iza.org/dp8817_supplement.pdf
} 


\section{Introduction}

Within the framework of active labor market policy (ALMP) in Germany, unemployed individuals are offered a monetary subsidy when starting their own business to exit unemployment. Start-up subsidies for unemployed individuals have a long tradition in Germany, constituting a significant part of German ALMP in the last decade. For instance, the Federal Employment Agency reports that 134,000 individuals were subsidized in 2011. Therefore, the number of entries is quite comparable to other large ALMP programs, such as wage subsidies $(187,000$ entries in the same year) or vocational training. Given the size of the program, it is highly relevant for policy makers to ascertain whether this is a successful strategy. As start-up subsidy programs are special ALMP programs due to the integration of participants in self-employment, policy makers are interested in their effectiveness from two perspectives: 1) from an ALMP perspective, it is interesting to know whether the program improves participants' labor market prospects; and 2) from a business/economic growth perspective, we want to know whether the subsidy leads to successful businesses, additional jobs and potentially innovation. An examination of both perspectives requires two different control groups. Based on comparisons of program participants with other unemployed individuals, previous studies have shown that start-up subsidies are effective from an ALMP perspective, improving participants' labor market outcomes (see Caliendo and Künn, 2011). An assessment of the second perspective requires a control group consisting of "regular", i.e. non-subsidized business start-ups.

Such an assessment is absolutely needed given that the existence of the subsidy might induce negative aspects that might offset/outweigh the positive evaluation from an ALMP perspective. First, it might involve deadweight losses, i.e. a situation where the same outcome would have been achieved even without the subsidy. Second, the existence of the subsidy bears the risk of adverse selection where individuals with less entrepreneurial ability enter self-employment because the required returns from self-employment (at which an individual is willing to become self-employed) are lower than without the subsidy. Finally, the subsidy could induce a moral hazard problem, leading to reduced effort and thus further reducing business growth.

Data limitations make empirical studies analyzing the effectiveness of subsidy programs for the unemployed from a business perspective scarce. For Germany, existing studies deliver no clear answer on whether subsidized businesses are comparable to regular businesses in terms of business performance (Hinz and Jungbauer-Gans, 1999; Pfeiffer and Reize, 2000). Furthermore, Niefert (2010) finds no shortages in terms of educational attainment but does find credit constraints for start-ups out of unemployment. However, the validity of the results is restricted due to data limitations, i.e., regional representativeness, the limited scope of available characteristics and cross-sectional information preventing an in-depth analysis of business development. From an international perspective, Andersson and Wadensjö (2007) compare business outcomes of self-employed individuals conditional on their prior employment status in Sweden. They find that start-ups out of employment perform best in terms of income and employment growth. Among those start-ups out of unemployment, the ones who received a start-up subsidy perform better than those without the subsidy. Désiage, Duhautois, and Redor (2012) compare previously unemployed 
or inactive business founders who did or did not receive a start-up subsidy in France. While subsidized start-ups have higher survival rates, they do not find evidence for higher economic performance with respect to number of employees and financial development among the subsidized firms. Hombert, Schoar, Sraer, and Thesmar (2013) find similar results when analyzing a reform in France that removed existing financial disincentives associated with starting a business out of unemployment. They find that businesses started out of unemployment after the reform were on average smaller but have similar growth paths than start-ups before the reform.

The main contribution of this paper is to introduce a new explorative dataset that allows an in-depth comparison between subsidized start-ups out of unemployment and regular business start-ups in Germany. For the group of subsidized start-ups out of unemployment, we use a random sample of entries into the start-up subsidy ("Gründungszuschuss", SUS) from the first quarter of 2009. The start-up subsidy provides unemployed individuals with financial assistance during the founding period (up to a maximum of 15 months). As regular business founders, we consider non-subsidized ${ }^{1}$ business start-ups from the first quarter of 2009. Since almost no unemployed person started a business without the subsidy during this time period, this group contains start-ups out of non-unemployment. Most importantly for our analysis, the same set of information was collected for both groups by means of extensive computer-assisted telephone interviews. Therefore, in contrast to previous studies, we are able to rely on a rich set of individual and business related information, as well as observing business development over time. The observation period ends 19 months after start-up allowing us a short-term analysis only.

Based on the new data, we examine three particular questions: First, unemployed individuals are expected to face disadvantages compared to regular start-ups in terms of more severe capital constraints, shortages in start-up specific human capital and networks, imperfect information and higher shares of necessity start-ups (mainly motivated by the pressure to cease unemployment). The new data allows us to examine whether such initial differences exist. Second, we ask how businesses founded by subsidized unemployed individuals perform compared to regular business start-ups, and finally, we want to know the magnitude of potential deadweight effects. To provide a brief preview of our results: 1) Nascent unemployed entrepreneurs indeed face disadvantages compared to regular business founders in variables correlated with entrepreneurial ability and access to capital; and 2) in terms of business performance, subsidized start-ups show higher survival rates 19 months after start-up, but lag behind regular business founders in terms of income, business growth and innovation. 3) Deadweight effects seem to exist, albeit at a much lower scale than usually assumed.

The remainder of this paper is organized as follows: Section 2 provides some economic considerations with respect to the subsidy's justification and impact on the selection into self-employment and business performance. Sections 3 provides relevant institutional settings in Germany. Section 4 describes the creation of our dataset and Section 5 contains the empirical analysis. Finally, Section 6 concludes.

\footnotetext{
${ }^{1}$ We use the term "non-subsidized" in the sense that individuals did not receive the start-up subsidy under scrutiny. However, this does not exclude receipt of other support, such as subsidized loans, counseling, etc.
} 


\section{Economic Considerations}

The aim of this Section is to discuss economic considerations justifying a start-up subsidy for the unemployed and potential mechanisms triggered by such a subsidy. Therefore, we first of all provide an overview of disadvantages that unemployed individuals are expected to face when starting their own business (compared to non-unemployed individuals), and how the subsidy is expected to remove such barriers. Since the introduction of a start-up subsidy for the unemployed might also lead to negative externalities such as deadweight effects, adverse selection or moral hazard among the recipients, these aspects and their consequences will be also discussed below. Finally, based on these considerations, we derive research questions that will be examined in the empirical part of the paper.

Disadvantages faced by unemployed nascent entrepreneurs: The existence of start-up subsidies for the unemployed relies on the assumption that nascent entrepreneurs among the unemployed face disadvantages compared to regular business founders. Such disadvantages might relate to different aspects. First of all, the unemployed are likely to face severe credit constraints. ${ }^{2}$ They tend to have lower financial means (personally and within family) compared to the non-unemployed population, which thus reduces the amount of personal equity available for business start-up. Moreover, capital markets are particularly likely to discriminate against unemployed individuals, which restricts access to loans (see Meager, 1996; Perry, 2006). For instance, unemployed individuals are more likely to have bad debt records, less wealth and less human capital, thus reducing their probability of receiving credit. ${ }^{3}$ Second, unemployed individuals might face disadvantages due to a depreciation of their start-up specific human and social capital during unemployment (Pfeiffer and Reize, 2000). This particularly includes the lack of experience of previous business foundation and industry-specific experience owing to less (self-)employment experience in the past. Beside the direct effect on the ability to start a business, it might further induce negative stigma effects in the sense that their businesses are discriminated by customers. Moreover, the lack of employment experience also induces disadvantages in terms of business and social networks, i.e. contact to potential customers, business partners or knowledge spillovers from colleagues (Niefert, 2010). Third, due to imperfect information unemployed individuals primarily focus on dependent employment and tend to ignore self-employment (Storey, 2003, refers to it as "lack-of-awareness"). The experience of labor market failure due to job loss reduces individuals self-confidence, making them less likely to consider self-employment as an alternative to dependent employment (Bönte and Jarosch, 2011, show that personality influences the decision to become selfemployed). Finally, start-ups out of unemployment are more likely necessity start-ups, namely unemployed individuals decide to become self-employed owing to missing employment alternatives. This is usually undertaken at short notice, with less time invested in

\footnotetext{
${ }^{2}$ General evidence on how credit constraints restrict the start-up rate can be found in Evans and Jovanovic (1989), Holtz-Eakin, Joulfaian, and Rosen (1994) and Schäfer, Talavera, and Weir (2011).

${ }^{3}$ Banks tend to screen individuals with respect to their human capital in the sense that it is negatively correlated with credit default risk, which renders individuals with higher human capital more capable and thus better access to credit.
} 
preparing the start-up, e.g. elaborating the business idea or marketing and financial strategy (Niefert, 2010). In this context, Shane (2003) argues that unemployed individuals have less access to information concerning business opportunities and lower opportunity costs, and consequently they also realize less valuable business ideas, introduce less innovation and hence earn smaller profits.

The role of the subsidy: The start-up subsidy aims at removing such barriers for the unemployed by providing financial assistance towards covering the cost of living and social security during the founding period. As explained above, owing to capital constraints, shortages in human capital, missing networks or time restrictions to explore business opportunities, nascent unemployed entrepreneurs are expected to have fewer resources available - than regular business founders - to prepare the business start-up. The subsidy is expected to compensate for these disadvantages. Moreover, in a recent study Bianchi and Bobba (2013) show that insurance (instead of credit) constraints are mostly binding for nascent entrepreneurs, i.e., the (financial) risk of failure hinders nascent entrepreneurs. In this sense, the subsidy can be considered as an insurance against the risk of low or no income during the start-up period stimulating nascent entrepreneurs among the unemployed to start a business. This might be particularly important for the unemployed due to low wealth. However, the existence of the subsidy might also induce some negative effects which are discussed below.

Adverse selection: Offering a subsidy bears the risk of opening the way to entrepreneurship for low ability individuals. In general, two different views exist in the literature on how individuals select into entrepreneurship when reducing existing barriers (see Hombert, Schoar, Sraer, and Thesmar, 2013): The experimentation view states that individuals do not have information about their entrepreneurial ability ex ante but learn their type by starting a business (Jovanovic, 1982). Therefore, barriers to entrepreneurship prevent the most constrained individuals from entrepreneurship who have similar or even better abilities as unconstrained individuals. On the contrary, the self-selection view states that individuals have full knowledge about their ability and self-select into entrepreneurship if expected returns exceed costs. Reducing the costs (e.g. due to a subsidy) allows less qualified individuals to enter (see also de Meza, 2002). While Hombert, Schoar, Sraer, and Thesmar (2013) find supportive evidence for the experimentation view, Nanda (2008) and Hvide and Møen (2007) show that reducing liquidity constraints drives adverse selection which supports the self-selection view.

Moral hazard: The subsidy payment might induce moral hazard (which might occur in addition to adverse selection as discussed before) inhibiting the survival-of-the-fittest mechanism. ${ }^{4}$ The economic concept of moral hazard predicts that individuals adjust their behavior if they do not have to take the full risk of their actions. Adopting this concept to the case of start-up subsidies, individuals might reduce their effort during subsidy receipt

\footnotetext{
${ }^{4}$ The survival-of-the-fittest mechanism states that due to competition and market selection, relatively high performing start-ups survive while low performing firms drop out the market (see Fritsch, 2008).
} 
as they - in contrast to non-subsidized businesses - do not have to take the cost, i.e. the risk of no or low income. ${ }^{5}$ However, as the subsidy is only paid temporarily, moral hazard is only present in the short-term, if at all. In the long run, the subsidy expires and subsidized individuals would also experience an income loss or even business failure if they reduce their effort.

Deadweight effects: In the context of policy evaluation, deadweight effects occur if the outcome under the treated situation would be exactly the same as without the treatment. Transferring this concept to start-up subsidies, it would require two criteria being fulfilled in order to identify deadweight effects: First, the subsidized individuals would have also become self-employed in the absence of the subsidy; and second, business success is uncorrelated with the subsidy (Caliendo and Kritikos, 2010). The identification of the second dimension is not straightforward and hence empirical evidence on the occurrence of deadweight effects is very limited, mainly due to data restrictions.

Resulting research questions: Based upon the above considerations, we derived three main aspects to consider in the empirical analysis.First, we are interested in a comparison of subsidized and regular business founders at the time of start-up, exploring the question whether the expected disadvantages faced by unemployed nascent entrepreneurs indeed exist. If yes, we should find differences in observed characteristics such as education background and access to capital. Second, we will consider the development of subsidized and regular businesses over time. In this regard, the economic considerations do not provide a clear indication. On the one hand, given that the experimentation view applies and the subsidy removed a financial barrier for constrained but similarly or more able individuals, we would expect similar or even better performance among the subsidized start-ups. Furthermore, the subsidy payment is expected to extend survival in self-employment, given that it increases profits and consequently the induced utility of remaining self-employed. In addition, the subsidy provides individuals with financial flexibility and releases resources to catch up with regular business founders. On the other hand, if the self-selection view dominates and adverse selection occurs, we would expect the opposite, given that individuals with lower entrepreneurial ability are expected to run smaller and probably low-profit businesses (de Wit, 1993; Pfeiffer and Reize, 2000). In addition to the entrepreneurship-specific literature, the occurrence of moral hazard might further slow down business development in the short run. Finally, as a third aspect we will investigate the occurrence of deadweight effects.

\footnotetext{
${ }^{5}$ This relies on the existence of asymmetric information, i.e. individuals who apply for the subsidy have more information than the institution that pays the subsidy. Once the subsidy is approved, the institution has no influence on the effort of the applicant. See Paulson, Townsend, and Karaivanov (2006) as an example for how moral hazard induces financial constraints on start-ups.
} 


\section{Start-up Subsidies for Unemployed Individuals in Ger- many}

The provision of start-up subsidies for unemployed individuals has been subject to several reforms during recent decades. Until August 2006, unemployed individuals wanting to start a business (including business takeovers or business inheritance) could choose between two different programs, which essentially differed in terms of subsidy's length and amount (see Caliendo and Künn, 2011, for a description). However, in August 2006, both programs were replaced by one single start-up subsidy program ("Gründungszuschuss", SUS), which is under scrutiny in this study. In order to be eligible for the subsidy, unemployed individuals had to have a minimum entitlement to unemployment benefit $I^{6}$ of at least 90 days at the time of program start. Moreover, individuals applying for the SUS had to provide a business and financing plan to the Employment Agency, which had to be evaluated by a competent external institution. If all requirements were fulfilled, SUS was paid for a maximum duration of 15 months, with the subsidy comprising of two parts: During the first nine months after business start-up, an amount equivalent to the individual's last unemployment benefit and a lump sum of 300 Euro to cover social security costs was paid monthly. ${ }^{7}$ After nine months, individuals could apply for an optional second period by sufficiently proving that their business is economically active. While the first period of SUS could be legally claimed by all individuals who fulfilled all legal requirements, the second period was entirely subject to the assessment of the respective case worker. Once the second period was approved, only the lump sum payment was granted for an additional period of six months. We find that $59.3 \%$ of the business founders in our sample received the subsidy for 15 months.

\section{INSERT Figure 1 ABOUt HERE}

In order to illustrate the magnitude of subsidized start-ups out of unemployment compared to all business start-ups in Germany, we show in Figure 1 the respective numbers for full-time business start-ups between 2006 and 2011. ${ }^{8}$ While information is available concerning the exact number of entries into SUS (based on the Statistic of the Federal Employment Agency), we have to rely on estimates for the number of all business founders based on population representative surveys, because Germany lacks a centralized administrative register for all business founders. The most frequently cited estimates are based on the German Microcensus and KfW Start-up Monitor. ${ }^{9}$ The difference between both

\footnotetext{
${ }^{6}$ In Germany, every individual who has been in employment subject to social security for at least one out of the last three years is eligible for unemployment benefit I. The amount of the benefit consists of $60 \%$ ( $67 \%$ with children) of the last net wage and is basically paid for a period of 12 months, with the exception of older individuals (see Caliendo and Hogenacker, 2012).

${ }^{7}$ Without program participation, the individuals would loose their unemployment benefit entitlement given that they start their own business and hence work full-time.

${ }^{8}$ In order to be eligible to SUS, founders have to set up their businesses full-time. Therefore, we compare them to all business start-ups that were also set up full-time.

${ }^{9}$ The KfW Start-up Monitor is an annual cross-section population survey, which currently contains 50,000 individuals between 18 and 65 years. The Microcensus is an annual representative survey capturing $1 \%$ of the German population and currently contains around 700,000 individuals. For further information, see KFW Bankengruppe (2012) and Fritsch, Kritikos, and Rusakova (2012).
} 
estimates mainly arises due to the identification of business start-ups: While the KfW start-up monitor identifies business founders based on a direct question (asking whether the respondent has started a business within the last 12 months), the Microcensus identifies business founders based on a change in employment status (i.e. individuals who are self-employed in the current wave but not in the previous year). As we can see, start-ups out of unemployment account for a significant share of all full-time business start-ups, ranging between $40 \%$ to $60 \%$ on average, depending on the data source.

\section{Data Creation}

The aim of this study is to provide a comprehensive comparison between subsidized startups out of unemployment and non-subsidized start-ups out of non-unemployment. As illustrated by the literature review above, existing datasets usually do not provide sufficient information to clearly identify both groups. Moreover, they are somewhat restricted with respect to individual information about the founder (such as human capital or intergenerational transmission) and longitudinal information on business development. Therefore, we create a new dataset that allows for such a comparison. Besides cross-sectional information on individual and business-related characteristics, the data contains information on business development over time. The data collection was achieved through a telephone survey, where the difficulty lay in finding a data source providing contact details for individuals who belong to our target population.

\section{INSERT Figure 2 ABOUt HERE}

As depicted in Figure 2, we used different data sources in order to realize a sample of subsidized and non-subsidized business start-ups. Subsidized start-ups out of unemployment are registered at the Federal Employment Agency and hence can be identified in the administrative data (Integrated Employment Biographies) provided by the Institute for Employment Research (IAB). However, the identification of non-subsidized start-ups is not straightforward, mainly due to the absence of a centralized register for all business founders in Germany. By contrast, a very decentralized industry-specific registration system exists, in the sense that business founders have to register with different institutions depending on their profession and location. Therefore, we relied on three different data sources to obtain contact information for non-subsidized start-ups: (1) the Chambers of Industry and Commerce ("Industrie- und Handelskammern", CCI), (2) the Chambers of Crafts ("Handwerkskammern", CC) and (3) a private address provider. As the underlying population is unknown, capturing these three data-bases can be considered a first attempt to construct such a sample of non-subsidized business start-ups.

Let us briefly discuss the three data sources. The Chambers of Industry and Commerce are public institutions with the main objective of representing of the interests of trading and manufacturing businesses. Subject to law, all businesses have to register with the CCI, 
with the exemption of particular professions, i.e. liberal professions ${ }^{10}$, craft enterprises and agriculture businesses. Given that subsidy receipt is not restricted to certain sectors, we also want to create a sample of non-subsidized business start-ups represented along the entire sectoral distribution. This is important because otherwise we would compare subsidized business founders (without restrictions on sectors) with a restricted sample of non-subsidized founders. Therefore, to complement the data basis with information on neglected professions, we also incorporate information from the Chambers of Crafts. Similar to CCI, CC are public institutions that represent the interests of businesses in the crafts sector, and thus record all crafts enterprises. Finally, we emphasize that despite liberal professions and agriculture businesses being officially exempted from registering at CCI or $\mathrm{CC}$, in practice they are usually covered given that they trade, produce or provide crafts services. The information from CCI and CC is finally complemented by addresses provided by a private address provider (PAP) to ensure regional representativeness of the sample as not every single chamber ${ }^{11}$ was willing to participate. The PAP obtains information based on its own research, as well as from the commercial register ("Handelsregister"). ${ }^{12}$ Since firms included in the commercial register are overrepresented in the PAP data, this complements well the addresses by CCI and CC for regional and occupational representativeness.

Finally, we extracted a random sample of business start-ups within the first quarter of 2009 from each data source, and collected the required information on these businesses by means of computer-assisted telephone interviews. ${ }^{13}$ The survey was collected about 19 months after business start-up. We provide detailed information on the implementation of the survey in the Supplementary Appendix (which is available online). As depicted in Figure 2, we realized a total of 2,306 interviews with subsidized businesses out of unemployment available for the empirical analysis, as well as 2,303 with non-subsidized businesses.

As previously mentioned, the creation of the dataset depicts a first attempt to construct such a sample of non-subsidized start-ups. In order to assess the representativeness of the finally realized sample of non-subsidized start-ups, we would like to compare it with the underlying population; however, this is unknown in our case which prohibits a representativity analysis. Therefore, the best we can do is to provide a comparison to a representative sample of all business start-ups in Germany instead, although this entails

\footnotetext{
${ }^{10}$ Subject to German law, liberal professions are defined as professions that require "higher vocational education or creativity", such as medical occupations (e.g. physicians, dentists), consultants (e.g. lawyers, tax accountants), technical or scientific occupations (e.g. engineers, architects) and the cultural sector (e.g. writer, musicians).

${ }^{11}$ In Germany, 80 Chambers of Industry and Commerce and 53 Chambers of Crafts exist in total.

${ }^{12}$ The commercial register contains firms who are actively involved in trading activities (so that large firms tend to be overrepresented). Its main objective is to provide security to business partners in the sense that they can rely on recorded firm-specific characteristics such as name, legal form, location, executive directors and the ability to pay liabilities.

${ }^{13}$ We note that having access to only one particular quarter of entrants might restrict the external validity of the results if the composition of business founders would change significantly over time. However, comparing the distribution of certain characteristics (e.g. age, education, migration, unemployment duration) across different quarters of entries into the subsidy program (based on the statistic of the Federal Employment Agency) does not show significant differences.
} 
the limitation that subsidized start-ups out of unemployment are also included. ${ }^{14}$ Based on information from the German Mircocensus (see Section 3 for details on the Microcensus and how start-ups are identified), we provide such a comparison between our realized sample of non-subsidized businesses and all business founders in Germany in 2009 in Table 1 (and separated by gender in Table A.1). It can be seen that we have relatively more men, older individuals and natives in our realized sample of non-subsidized businesses. Moreover, the share of business founders located in East Germany is lower in our sample. With respect to professional education, we find equal shares of skilled workers; however, within tertiary education, we find fewer individuals with a university degree and more master craftsmen (holding a technical college degree). Finally, we compare the sectoral distribution and find similar shares in agriculture, construction, crafts and information technology, financial and insurance service while some significant differences exist in terms of remaining sectors. However, the comparison does not reveal whether the realized sample of non-subsidized start-ups is representative towards the population of non-subsidized start-ups (as mentioned above) but rather should help the reader to assess the constructed sample.

\section{INSERT TABLE 1 ABOUT HERE}

For the empirical analysis, it is necessary to further restrict the sample of non-subsidized businesses in order to align it towards the subsidized start-ups out of unemployment. First of all, we only keep non-subsidized business founders who started their business full-time, given that this is also required for the SUS recipients. Secondly, we dropped all business founders who had been unemployed immediately before start-up, as we want to compare subsidized start-ups out of unemployment to non-subsidized start-ups out of nonunemployment. Accordingly, these two restrictions reduce the size of the non-subsidized founders from 2,303 down to 1,529 observations (see Figure 2). ${ }^{15}$ Finally, we highlight that we will denote the group of subsidized start-ups out of unemployment as "subsidized start-ups" throughout the remainder of the paper, and our comparison group consisting of non-subsidized start-ups out of non-unemployment as "regular start-ups".

\section{Empirical Analysis}

Based on this dataset, the empirical analysis addresses the research questions derived in Section 2. We restrict the empirical analysis to male individuals. ${ }^{16}$ Male and female business founders significantly differ in several aspects. While men are represented along the entire distribution of entrepreneurs, female entrepreneurs tend to be concentrated in

\footnotetext{
${ }^{14}$ According to the reporting system of the German Kreditanstalt für Wiederaufbau, of all business startups in Germany, 21.4\% self-reported having started out of unemployment in 2009 (KfW Bankengruppe, 2010).

${ }^{15}$ Out of the initial sample of 2,303 individuals, 132 business founders were excluded from the data because they started out of unemployment. Out of the remaining sample of 2,171 observations, a further 642 founders who started their self-employment part-time were excluded.

${ }^{16}$ See Caliendo and Künn (2015) for evidence on subsidized start-ups out of unemployment by females.
} 
particular sectors, and among low performance businesses, i.e. in terms of profits, survival, growth rates and income, mainly because women tend to seek work-family balance rather than earning maximization (Klapper and Parker, 2011; Boden, 1999). These differences between male and female entrepreneurs are also reflected in working hours, with women significantly less likely to become full-time self-employed (Gurley-Calvez, Biehl, and Harper, 2009; Lechmann and Schnabel, 2012). ${ }^{17}$ Given that we only focus on full-time start-ups (as this is one of the eligibility criteria for subsidy receipt), we are concerned that we would analyze a selected sample of female entrepreneurs (not representative of the entire population of female entrepreneurs), which would limit the external validity of the results for women in this analysis. For men this is not an issue since the vast majority runs their business in full-time. Therefore, we exclude women and finally observe 1,478 (930) male subsidized (regular) business founders.

\subsection{Do Subsidized Start-ups Differ from Regular Start-ups?}

As described in Section 2, start-ups out of unemployment are expected to face disadvantages compared to regular business founders in terms of capital constraints, shortages in start-up specific human capital, missing networks and restricted access to information about business opportunities. Therefore, unemployed individuals are offered a subsidy in order to compensate for such initial disadvantages. However, the existence of the subsidy bears the risk of adverse selection.

To investigate the empirical relevance of the expected disadvantages and shortages for subsidized start-ups, we provide a descriptive comparison between subsidized start-ups with regular business founders at the time of start-up. Thereby, we consider individual and business related characteristics in Table 2 that reflect the aforementioned disadvantages.

However, it is necessary to highlight a limitation of this analysis. In order to identify the existence of disadvantages faced by unemployed individuals, one would actually need to compare nascent entrepreneurs among the unemployed with nascent entrepreneurs among the non-unemployed, which would reflect the true extent of disadvantages. However, given that it is very hard to identify nascent entrepreneurs, we rely on business founders instead. Consequently, this limits the validity of the results, as out of all nascent entrepreneurs finally realized businesses start-ups by unemployed and non-unemployed individuals are likely to being more homogenous. For instance, individuals with very severe financial constraints (which are most likely overrepresented among the unemployed) are relatively less likely to make their way from a nascent entrepreneur to business founder. Additionally, the subsidy induces individuals who would have founded a business out of non-unemployment to register as unemployed in order to receive the subsidy and therefore now belong to the group of start-ups out of unemployment. This will further enforce the homogeneity of business founders out of unemployment and non-unemployment. Therefore, comparing business founders (rather than nascent entrepreneurs) is likely to reflect a lower bound estimation of the true level of disadvantages that unemployed individuals actually face.

\footnotetext{
${ }^{17}$ The German Federal Statistical Office reports for 2009 that $55 \%$ of female entrepreneurs work 40 hours/week or more while this amounts to $86 \%$ for male founders.
} 
Motivation: Results in Table 2 suggest that "push motives" are overrepresented among subsidized business founders. While no significant differences exist for the two "pull motives" ("I wanted to be my own boss" and "I wanted to earn more money"), we find significant higher shares of unemployed business founders reporting the two "push motives" ("Advice from external institution (Employment Agency etc)" and "No employment alternative"). This suggests that necessity rather than opportunity reflects the dominant motivation among start-ups out of unemployment.

Human Capital and Networks: Human capital and existing networks play an important role for setting up and running a business (Parker, 2009). In order to reveal the disadvantages faced by the unemployed in this regard, we have measures available concerning formal education, employment and industry-specific experiences, and intergenerational transmission.

Starting with formal education, Table 2 shows no significant differences with respect to school degrees for subsidized business founders. In terms of professional education, we find significant differences compared to regular business founders, but no clear pattern. Higher shares of previously unemployed business founders have an apprenticeship or university degree, while regular business founders are more likely to have graduated from a technical college or have another degree. Overall, we do not find clear evidence that subsidized business founders face disadvantages in terms of formal education. However, against the background of previous findings, our results are not very surprising given that general education has been shown to have only a moderate influence on the start-up decision (van Praag, van Sluis, and Vijverberg, 2008; Ucbasaran, Westhead, and Wright, 2008).

Another important aspect of human capital concerns employment and industry-specific experience of the founders, which can also be an indicator for the size and quality of existing networks (e.g. through contacts to potential customers or potential business partners). Table 2 shows that subsidized business founders have on average less employment (and more unemployment) experience, thus indicating a disadvantage. For instance, subsidized founders spent on average nine months less in employment (and eight months more in unemployment) than regular business founders during their working life (based on a mean age of 40 years). Regarding industry-specific experience, we detect a similar pattern. Table 2 shows that subsidized business founders primarily acquired industry-specific experience from dependent employment while regular business founders are significant more likely to have industry-specific experience from previous self-employment. This depicts a significant advantage for regular business founders as they had realized a business start-up before and hence are likely to have valuable business networks, existing contacts to customers, etc., whereas subsidized start-ups generally do not have this experience.

Finally, we investigate differences in terms of intergenerational transmission, i.e., selfemployed parents transmit start-up specific abilities, existing businesses and networks to their children, which has been shown to have a significant influence on business performance over time (Tervo, 2006; Fairlie and Robb, 2007). Table 2 shows that regular 
business founders are significantly more likely to have self-employed parents (and to experience intra-family business takeover) and hence are benefiting potentially more from intergenerational transmission of start-up specific abilities, networks and businesses.

Capital Investments and Constraints: Finally, we consider capital investments realized at business start-up and within the founding period. As derived in Section 2, business founders out of unemployment are expected to have lower financial means and face a higher risk of being discriminated by capital markets, which restricts their access to loans. We clearly find supportive evidence that subsidized start-ups invest less capital in Table 2. While the share of individuals who invested capital at start-up is similar in both groups, at $82 \%$, we find substantial differences in the invested amount. Regular business founders invest significantly more (44,170 Euro) capital at start-up than subsidized ones $(21,740$ Euro). This effect is not driven by statistical outliers, as the median, the maximum and the share with 50,000 Euro and more in Table 2 show. ${ }^{18}$

However, the question remains whether this gap is due to differences in available personal equity or access to loans. While we do not have detailed information on overall personal equity, we observe the share of the invested capital that has been financed by personal equity. Here, we find no significant differences between both groups, i.e. business founders finance on average $70 \%$ of the start-up capital by personal equity. Therefore, constraints in terms of personal equity might eventually lead to less capital investment. Moreover, we find supportive evidence that the unemployed also face more restricted access to loans. Table 2 shows that only $20 \%$ of subsidized start-ups received a loan, which was the case for $29 \%$ of regular business founders. However, the pure take-up rate does not necessarily indicate credit constraints as subsidized individuals might simply have less demand for loans due to the subsidy. The credit constraint argument becomes more evident in the following statistic: $16 \%$ of all subsidized start-ups report that they received no loan but would have liked to, while this only applies to $10 \%$ among the regular business founders. Although we are unable to identify whether those individuals actually tried to apply for a loan in the end, we interpret this pattern as suggestive evidence for existing credit constraints in terms of the accessability of loans for the unemployed. Finally, we provide evidence on the take-up of other types of support. Table 2 shows no differences in terms of receiving a subsidized loan but a higher share of subsidized founders received a business coaching.

In summary, subsidized start-ups seem to have no shortages in terms of formal education; however, they have less employment and industry-specific experience, and fewer spillovers from intergenerational transmission. Moreover, we find evidence that necessity start-ups are overrepresented among business founders out of unemployment, suggesting disadvantages in terms of business preparation, owing to time restrictions. Finally, we detect capital constraints among the unemployed in terms of both the availability of personal equity and access to loans.

\footnotetext{
${ }^{18}$ The KfW Bankengruppe (2009) reports that among all founders who started a business in full-time in Germany in 2009, $80 \%$ invested capital at start-up (which is very similar to our estimation sample) from which $10.5 \%$ invested 50,000 Euro and more (which is in the middle of the two groups under scrutiny).
} 


\subsection{Business Development}

\subsubsection{Econometric Strategy}

Given the existence of disadvantages for subsidized start-ups compared to regular startups, we now address the question of how subsidized businesses perform compared to regular businesses. Based on economic considerations, the subsidy is expected to have two opposing effects on business survival and growth (see Section 2). The question that we address is what would have happened if the subsidized unemployed person had started a business out of non-unemployment without the subsidy. To answer this question, we actually want to compare the development of a business started by an unemployed individual (with subsidy receipt) with a business started out of non-unemployment by the same individual. However, given that we only observe each individual either as previously unemployed or as regular business founder, we have to estimate the counterfactual situation for subsidized business founders. To do so, we use the group of regular business founders.

However, an unconditional comparison of outcome variables $(Y)$ between subsidized $(\mathrm{D}=1)$ and regular $(\mathrm{D}=0)$ founders, i.e., $\tau^{\text {raw }}=E(Y \mid D=1)-E(Y \mid D=0)$, is not very informative given that substantial differences in terms of observable characteristics exist (as shown in the previous section in Table 2 and Table A.2 in the Appendix). In addition to the differences in observable characteristics, both groups might further differ in terms of unobserved characteristics. Therefore, we will use a decomposition method to disentangle the influence of both parts. Instead of using traditional decomposition methods such as the Blinder-Oaxaca decomposition (which is based on linear regression models), we follow Frölich (2007) and use propensity score matching (PSM) ${ }^{19}$ for two reasons: (i) The regression function to construct the counterfactual outcome is not specified to be linear but is based on a non-parametric estimation (adjusted means). (ii) The PSM decomposition method also imposes a common support restriction and hence avoids the out-of-support assumption that is required when using Blinder-Oaxaca decomposition (assuming that the linear estimators of the outcomes are also valid in regions of individual characteristics where there is no common support).

Based on PSM (see Caliendo and Kopeinig, 2008, for details on the implementation of PSM), we align the group of regular business founders towards the group of subsidized start-ups in terms of observable characteristics. However, instead of interpreting the estimated gap in outcome variables as the causal average treatment effect on the treated (ATT), as conducted in the evaluation literature (Rosenbaum and Rubin, 1983; Imbens and Wooldridge, 2009), we interpret the gap as a conditional gap:

$$
\tau^{\text {cond }}=E(Y \mid D=1)-E_{P(X)}[E(Y \mid P(X), D=0) \mid D=1],
$$

where the first term can be directly estimated from the group of subsidized founders. The second term is the adjusted mean from the matched group of regular founders using propensity score $\mathrm{P}(\mathrm{X})$ matching.

The calculation of the counterfactual outcome (second term in Equation 1) helps to

\footnotetext{
${ }^{19}$ See Caliendo and Lee (2013) and Krause, Rinne, and Schüller (2014) for similar applications using matching to perform decomposition.
} 
answer the question of how regular business founders would perform if they had the same distribution of observable characteristics as subsidized business founders. The remaining gap to the outcome of the subsidized founders $\left(\tau^{\text {cond }}\right)$ is subsequently interpreted as a conditional gap that remains unexplained by observable characteristics. The rich data allow us to control for a large vector of observable characteristics including labor market history and important information about the start-up (see Table A.2), which are correlated with personality and thus should significantly reduce the remaining influence of unobserved differences. Based on economic considerations, $\tau^{\text {cond }}$ might be explained by the receipt of the subsidy, disadvantages arising from the unemployment status of the subsidized founders and adverse selection or moral hazard as induced by the subsidy. Finally, to avoid any misinterpretation, we emphasize that $\tau^{\text {cond }}$ (in contrast to the evaluation literature where matching is usually applied) has no causal interpretation here, as it simply reflects a conditional gap after having controlled for observable characteristics. Details on the implementation of the matching procedure including a list of all observable characteristics as well as the balancing characteristics are shown in Appendix A.2.

\subsubsection{Results}

To answer the question of how subsidized start-ups perform over time compared to regular business founders, Table 3 shows results with respect to survival in self-employment, income and business growth, as measured by the employee structure 19 months after business start-up. Note that subsidy receipt has been fully expired for at least four months at this time (see Section 3).

First of all, we focus on results for the full sample (upper part in Table 3). It can be seen that 19 months after start-up, $80.7 \%$ of subsidized business founders remain selfemployed compared to $72.6 \%$ in the case of regular business founders, indicating higher survival among the subsidized businesses. However, the question is to what extent this raw difference is driven by differences in observable characteristics. Column (3) shows the conditional share estimated by propensity score matching. It can be observed that controlling for observable characteristics reduces the outcome gap from initially $8.1 \%$ (raw) to $6.3 \%$ (conditional). However, the remaining conditional gap of $6.3 \%$-points is statistically significant and therefore still indicates higher survival for subsidized start-ups. This might be explained by subsidy receipt. It seems that the direct effect of the subsidy payment during the founding period dominates initial disadvantages arising from unemployment and by the subsidy potentially induced negative effects such as adverse selection or moral hazard. Regarding those who failed to remain self-employed, we do not find any significant differences between both groups in terms of integration in dependent employment or unemployment after having controlled for observable differences. With respect to working income, Table 3 shows significant higher net earnings for regular business founders, which is largely attributable to existing differences in observable characteristics. After having controlled for these differences, regular businesses have a net monthly working income of 2,500 Euro on average which is not significantly different to the monthly earnings of subsidized business founders.

Conditional on still being self-employed, Table 3 shows further business outcomes, 
highlighting significantly lower net income and less business growth for subsidized compared to regular business founders. For instance, 19 months after start-up, previously unemployed and subsidized business owners earn on average 2,389 Euro per month from their self-employed activity, which is, conditional on observable characteristics, 684 Euro less than regular business founders earn. However, despite the net income of subsidized founders being smaller compared to regular founders, it still exceeds monthly net earnings of a comparable full-time employee in Germany, which corresponded to about 1,900 Euro per month in 2010 (Caliendo, Hogenacker, and Künn, 2012). Moreover, only $36.1 \%$ of previously subsidized business owners employ on average three full-time equivalent workers, compared to $56.5 \%$ employing on average six full-time equivalent workers among the regular business founders; whereby the conditional differences are also statistically significant. ${ }^{20}$

\section{INSERT TABLE 3 ABOUT HERE}

Finally, we shed light on the empirical relevance of the argument that start-ups out of unemployment implement less innovation due to restricted access to information concerning business opportunities or missing pull motives (Shane, 2003; Caliendo and Kritikos, 2009). Indeed, Table 3 confirms this expectation: After having controlled for observable characteristics, regular business founders are more likely to file a patent (not statistically significant though) or application to protect corporate identity (which is also statistically significant). This reflects the higher degree of innovation implemented by these firms during the first 19 months after start-up.

In summary, Table 3 suggests that subsidized start-ups face higher business survival, but lag behind regular business founders in terms of income, business growth and innovation. The extended survival might be explained by the subsidy payment as it increases income and consequently the utility of remaining self-employed. Although a direct effect due to ongoing subsidy receipt can be excluded, it might be the case that the measurement 19 months after start-up is still influenced by recent subsidy expiration. ${ }^{21}$ The lower income and growth rates might be explained by different issues: First, subsidized founders might face disadvantages arising from their initial unemployment status (in addition to observed aspects), e.g., discrimination at capital markets or smaller networks. Second, the subsidy could induce adverse selection in self-employment resulting in lower business performance. In contrast to Hombert, Schoar, Sraer, and Thesmar (2013), our results support the self-selection view where less qualified individuals self-select into entrepreneurship due to reduced costs of entry which is in line with findings by Nanda (2008) and Hvide and Møen (2007). Third, the presence of the subsidy might have reduced business growth due to moral hazard by inhibiting the selection process of profitable and non-profitable businesses (survival-of-the-fittest). Within the regular businesses only the profitable businesses survive and grow larger than subsidized businesses where also non-profitable or

\footnotetext{
${ }^{20}$ This means that all subsidy recipients in the first quarter of $2009(\mathrm{~N}=31,365)$, created approximately 27,500 jobs until the end of 2010 .

${ }^{21}$ The capital-intensive first part of the subsidy payment, i.e. unemployment benefit plus lump-sum payment of 300 Euro/month, has already expired for 10 months, and the optional second part, consisting of the lump-sum payment of 300 Euro/month only, for four months.
} 
low-profitable businesses are represented.

The question remains whether the identified gaps are persistent or will disappear after a while. In the long run, former subsidized firms have to survive and compete in the market without the subsidy and therefore might converge towards regular business founders. This is left for future research.

\subsection{Deadweight Effects}

Finally, we consider the occurrence of deadweight effects. As illustrated in Section 2, the identification of deadweight effects related to start-up subsidies requires that two criteria have to be fulfilled: First, the subsidized individual would have become self-employed even in the absence of the subsidy; and second, the subsidy must have had no impact on business success. Due to data restrictions, previous studies have had to rely on information only concerning the first criteria only (e.g. Lenihan, 2004; Caliendo and Kritikos, 2010; Tokila, Haapanen, and Ritsilä, 2008). We are now able to go one step further and also consider the second dimension.

\section{INSERT TABLE 4 ABOUT HERE}

Starting with descriptive evidence, Table 4 shows that two variables describe the first dimension, i.e. whether individuals would have become self-employed even without the subsidy. Using the broader definition represented by statement 1, we can see that $48.3 \%$ of the subsidized business founders are potentially affected by deadweight effects, as they report that they would have even founded a business in the absence of the subsidy. Using a much narrower definition, i.e. whether individuals intentionally registered as unemployed to receive the subsidy (statement 2), we observe that only $22.8 \%$ are potentially affected. Before considering the second dimension, we want to recap that those shares have been often cited within former studies and the political discussion with respect to the occurrence of deadweight effects. ${ }^{22}$

We have now data available that allows the consideration of the second dimension, i.e. the importance of the subsidy for business survival during the first six months. We would actually expect that the subsidy had little or no relevance for individuals who would have even become self-employed without the subsidy (48.3\%) or intentionally registered as unemployed to receive the subsidy (22.8\%). However, Table 4 shows that this is not the case. Taking the second dimension into account significantly reduces the shares that are potentially affected by deadweight effects. For instance, the share of $48.3 \%$ that is potentially affected by deadweight effects reduces to $21.3 \%$, with only those individuals having reported that the subsidy had no impact on business survival. For the remaining share, the subsidy had at least some impact on business success and hence has to be excluded from the share that is potentially affected by deadweight effects. Using the narrow definition of the first dimension, the potentially affected share is reduced from $22.8 \%$ to only $8.6 \%$.

\footnotetext{
${ }^{22}$ See, e.g. Bundesministerium für Arbeit und Soziales und Institut für Arbeitsmarkt und Berufsforschung (2011)
} 
Despite respondents being surveyed 19 months after the business start-up and hence answers might be correlated with business success ${ }^{23}$, we argue that the results provide essential new insights by showing that the share potentially affected by deadweight effects is much smaller than usually assumed.

However, in order to ultimately conclude that this is the true amount of deadweight effects, we would need to compare business outcomes of the subgroup of subsidized founders that is potentially affected by deadweight effects $(21.3 \%$ and $8.6 \%)$ to non-subsidized business start-ups to exclude any impact of the subsidy on business success (beyond the founding period). As we have a control group available consisting of non-subsidized business start-ups out of non-unemployment, we can run such a comparison but only for the subgroup of $8.6 \%$. Only for this subgroup of subsidized founders, we can reliably assume that they would have started a business out of non-unemployment in the absence of the subsidy and hence would belong to the group of regular business founders, given that they have reported that they intentionally registered as unemployed to receive the subsidy. ${ }^{24}$ Therefore, given that we find no differences in business outcomes between this subgroup and regular founders, we could conclude that $8.6 \%$ of the subsidized founders are certainly affected by deadweight effects.

\section{INSERT TABLE 5 ABOUT HERE}

Based on the econometric strategy as outlined in Section 5.2.1, Table 5 shows such a comparison for selected outcome variables. We only present conditional values, i.e. after having controlled for differences in observable characteristics. As we can see, the same pattern as in Table 3 arises, with subsidized businesses showing higher survival rates 19 months after start-up, but lag behind regular businesses in terms of income, business growth and innovation.

Although the identification of deadweight effects relies on survey information measured 19 months after start-up (see Section 5.3) and differences in income and innovation are not statistically significant (due to the lower number of observations compared to Table 3 ), the results indicate that the share affected by deadweight effects must be even smaller than $8.6 \%$ as the subsidy still had some impact on business success for this subgroup.

\footnotetext{
${ }^{23}$ We do not expect that misreporting is a big issue here because each respondent was informed (by a letter and at the beginning of each interview) that their answers will be treated absolutely anonymous and public institution such as the Employment Agency will have never access to the data.

${ }^{24}$ We neglect results for the subgroup of $21.3 \%$ that is potentially affected by deadweight effects using the broad definition (see Table 4) as we cannot assume that this group would have started out of non-unemployment (and hence belong to regular business founders). Here, the adequate control group would consist of non-subsidized start-ups out of unemployment, which is difficult to create as almost no unemployed person starts a business without the subsidy in Germany. However, point estimates using our available control group indicate a similar pattern as for the share of $8.6 \%$. Results are available online in the Supplementary Appendix.
} 


\section{Conclusion}

This study investigates differences between subsidized start-ups out of unemployment and non-subsidized start-ups out of non-unemployment, thereby addressing three particular questions: First, do initial differences between subsidized start-ups out of unemployment and regular business start-ups exist? Second, how do businesses founded by subsidized unemployed individuals perform compared to regular business founders? And third, do deadweight effects occur? Due to data restrictions, the empirical evidence on these questions has been very limited to date. This study uses a new data set based on a telephone survey making such a comparison possible. In addition to cross-sectional information on individual and business-related characteristics, the data also contains information on business development over time.

With respect to initial differences between subsidized and regular start-ups, we find that founders of subsidized start-ups seem to have no shortages in terms of formal education. However, they have less employment and industry-specific experience, and fewer spillovers from intergenerational transmission. Moreover, we find evidence that necessity start-ups are overrepresented among subsidized business founders, suggesting disadvantages in terms of business preparation due to time restrictions. Finally, we detect capital constraints among the unemployed in terms of both the availability of personal equity and access to loans.

Given the detected differences at business start-up, we further investigate its influence on business performance over time. Using propensity score matching as a decomposition method, we disentangle which part of the observed differences in business performance is due to differences in observable characteristics of business founders and which is due to the subsidy and related unobserved heterogeneity such as adverse selection or moral hazard. Results indicate that subsidized start-ups out of unemployment face higher business survival rates 19 months after start-up, however, lag behind regular business founders in terms of income, business growth and innovation. The differences in business performance might be explained by different issues. First, given that the subsidy payment has recently expired, it might still have an ongoing positive effect on business survival. Second, subsidized founders might face disadvantages arising from their initial unemployment status (in addition to observed aspects), e.g., discrimination at capital markets or smaller networks. Third, adverse selection due to the subsidy could negatively impact business development. In contrast to Hombert, Schoar, Sraer, and Thesmar (2013), our results seem to support the self-selection view where less qualified individuals self-select into entrepreneurship due to reduced costs of entry which is in line with findings by Nanda (2008) and Hvide and Møen (2007). Fourth, the subsidy payment induces moral hazard hindering the market mechanism, i.e. the selection process of profitable and not profitable businesses (survivalof-the-fittest). Future research needs to investigate whether the identified gaps remain in the longer run, or if subsidized and regular businesses converge once the subsidy receipt is far behind.

Finally, the new data also allows for the first time a deeper analysis of deadweight effects because it contains both detailed information on the importance of the subsidy for business start-up and in addition its potential influence on business outcomes. In particular 
the consideration of the latter issue was missing in previous studies due to data restrictions. Although the identification of deadweight effects relies on survey information measured 19 months after start-up, our analysis confirms the existence of deadweight effects (as found by previous studies), but at a (much) lower scale than usually assumed.

Although the observation period is limited to 19 months after start-up, the findings in this paper suggest that the subsidy indeed helps unemployed individuals to set up a business and survive the critical founding period; however, it also seems to induce a negative bias in terms of business performance. Therefore, the findings complement the overall picture with respect to the effectiveness of the subsidy program. The subsidy helps unemployed individuals to sustainably escape unemployment (effective as an ALMP program), however, it does not spur business growth and innovation (less successful from a business perspective). Although we cannot make final statements based on short-term results, the latter finding should concern policy makers if subsidized businesses are proven to persistently lag behind. 


\section{References}

Andersson, P., and E. Wadensjö (2007): "Do the Unemployed Become Successful Entrepreneurs?," International Journal of Manpower, 28(7), 604-626.

Bianchi, M., and M. Bobba (2013): "Liquidity, Risk, and Occupational Choices," Review of Economic Studies, 80, 491-511.

Bönte, W., And M. Jarosch (2011): "Gender Differences in Competitiveness, Risk Tolerance, and other Personality Traits: Do they contribute to the Gender Gap in Entrepreneurship?," Schumpeter Discussion Paper 2011-012, Schumpeter School of Business and Economics, at the University Wuppertal.

Boden, R. J. (1999): "Flexible Working Hours, Family Responsibilities, and Female SelfEmployment: Gender Differences in Self-Employment Selection," American Journal of Economics and Sociology, 58(1), 71-83.

Bundesministerium für Arbeit und Soziales und Institut Für ArbeitsmarkT UND BERUFSFORSCHUNG (2011): "Sachstandsbericht der Evaluation der Instrumente," Forschungsbericht, Berlin, Nürnberg.

Caliendo, M., And J. Hogenacker (2012): "The German Labor Market after the Great Recession: Successful Reforms and Future Challenges," IZA Journal of European Labor Studies, 1:3.

Caliendo, M., J. Hogenacker, and S. Künn (2012): "Alte Idee, neues Programm: Der Gründungszuschuss als Nachfolger von Überbrückungsgeld und Ich-AG," Journal of Labor Market Research, 45(2), 99-123.

Caliendo, M., and S. KÜnn (2011): "Start-Up Subsidies for the Unemployed: LongTerm Evidence and Effect Heterogeneity," Journal of Public Economics, 95(3-4), 311331.

(2015): "Getting Back into the Labor Market: The Effects of Start-Up Subsidies for Unemployed Females," forthcoming in: Journal of Population Economics.

Caliendo, M., and S. Kopeinig (2008): "Some Practical Guidance for the Implementation of Propensity Score Matching," Journal of Economic Surveys, 22(1), 31-72.

Caliendo, M., And A. KRitikos (2009): "I Want to, But I Also Need to": Start-Ups Resulting from Opportunity and Necessity," Discussion Paper 4661, IZA.

Caliendo, M., and A. Kritikos (2010): "Start-Ups by the Unemployed: Characteristics, Survival and Direct Employment Effects," Small Business Economics, 35(1), 71-92.

Caliendo, M., and W.-S. Lee (2013): "Fat chance! Obesity and the transition from unemployment to employment," Economics \& Human Biology, 11, 121-133.

DE MezA, D. (2002): "Overlending," The Economic Journal, 112, F17-F31.

DE Wit, G. (1993): "Models of Self-Employment in a Competitive Market," Journal of Economic Surveys, 7(4), 367-397.

Désiage, L., R. Duhautois, and D. Redor (2012): "Long Term Effect of Public Subsidies on Start-up Survival and Economic Performance. An Empirical Study with French Data," TEPP Working Paper 2010-4, TEPP - Institute for Labor Studies and Public Policies.

Efron, B., And T. R. J (1993): An Introduction to the Bootstrap. Chapman and Hall, New York. 
Evans, D., And B. Jovanovic (1989): "An Estimated Model of Entrepreneurial Choice under Liquidity Constraints," Journal of Political Economy, 97, 808-827.

Fairlie, R. W., And A. M. RobB (2007): "Why Are Black-Owned Businesses Less Successful than White-Owned Businesses? The Role of Families, Inheritances, and Business Human Capital," Journal of Labor Economics, 25(2), 289-323.

Fritsch, M. (2008): "How does New Business Development Affect Regional Development? Introduction to the Special Issue," Small Business Economics, 30, 1-14.

Fritsch, M., A. Kritikos, and A. Rusakova (2012): "Who Starts a Business and Who is Self-Employed in Germany," Discussion Paper 6326, IZA.

FrÖLICH, M. (2007): "Propensity Score Matching without Conditional Independence Assumption - With an Application to the Gender Wage Gap in the United Kingdom," Econometrics Journal, 10, 359-407.

Gurley-Calvez, T., A. Biehl, and K. Harper (2009): "Time-Use Patterns and Women Entrepreneurs," American Economic Review: Papers and Proceedings, 99(2), $139-144$.

Hinz, T., And M. JungBaueR-Gans (1999): "Starting a Business after Unemployment: Characteristics and Chances of Success (Empirical Evidence from a Regional German Labour Market)," Entrepreneurship and Regional Development, 11, 317-333.

Holtz-Eakin, D., D. Joulfaian, and H. S. Rosen (1994): "Entrepreneurial Decisions and Liquidity Constraints," The RAND Journal of Economics, 25(2), 334-347.

Hombert, J., A. Schoar, D. Sraer, and D. Thesmar (2013): "Can Unemployment Insurance Spur Entrepreneurial Activity? Evidence From France," Working Paper, HEC Paris.

Hvide, H. K., And J. Møen (2007): "Liquidity Constraints and Entrepreneurial Performance," Discussion Paper 6495, CEPR.

Imbens, G., And J. M. Wooldridge (2009): "Recent Developments in the Econometrics of Program Evaluation," Journal of Economic Literature, 47(1), 5-86.

Jovanovic, B. (1982): "Selection and the Evolution of Industry," Econometrica, 50(3), 649-670.

KFW BANKengruppe (2009): KfW-Gründungsmonitor 2009.

(2010): KfW-Gründungsmonitor 2010.

KFW BANKENGRUPPE (2012): KfW-Gründungsmonitor 2012.

Klapper, L. F., and S. C. PARker (2011): "Gender and the Business Environment for New Firm Creation," The World Bank Research Observer, 26(2), 237-257.

Krause, A., U. Rinne, And S. Schüller (2014): "Kick It Like Özil? Decomposing the Native-Migrant Education Gap," International Migration Review, DOI: 10.1111/imre.12107.

Kreditanstalt Für Wiederaufbau (2012): "KfW-Gründungsmonitor 2012. Jährliche Analyse von Struktur und Dynamik des Gründungsgeschehens in Deutschland," Frankfurt.

Lechmann, D., and C. Schnabel (2012): "Why is there a gender earnings gap in selfemployment? A decomposition analysis with German data," IZA Journal of European Labor Studies, 1(6). 
Lenihan, H. (2004): "Evaluating Irish Industrial Policy in Terms of Deadweight and Displacement: A Quantative Methodological Approach," Applied Economics, 36, 229252.

Meager, N. (1996): "Self-Employment as an alternative to dependent employment for the unemployed," in International Handbook of Labour Market Policy and Evaluation, ed. by G. Schmid, J. O'Reilly, and K. Schömann, pp. 489-519. Edward Elgar.

NANDA, R. (2008): "Cost of External Finance and Selection into Entrepreneurship," Working Paper 08-047, Harvard Business School.

Niefert, M. (2010): "Characteristics and Determinants of Start-ups from Unemployment: Evidence from German Micro Data," Journal of Small Business and Entrepreneurship, $23,409-429$.

Parker, S. C. (2009): The Economics of Entrepreneurship. Cambridge University Press, New York, Cambridge.

Paulson, A. L., R. M. Townsend, and A. Karaivanov (2006): "Distinguishing Limited Liability from Moral Hazard in a Model of Entrepreneurship," Journal of Political Economy, 114(1), 100-144.

Perry, G. (2006): "Are Business Start-Up Subsidies Effective for the Unemployed: Evaluation of Enterprise Allowance," Working paper, Auckland University of Technology.

Pfeiffer, F., And F. Reize (2000): "Business Start-Ups by the Unemployed - an Econometric Analysis Based on Firm Data," Labour Economics, 7, 629-663.

Piorkowsky, M., And M. Buddensiek (2011): Selbständige in Deutschland 2006-2010 - mit einer Sonderauswertung nach Wirtschaftsbereichen 1996-2008: Der Selbständigen-Monitor mit dem vollständigen Datensatz des Mikrozensus des Statistischen Bundesamtes. Universität Bonn.

Rosenbaum, P., and D. Rubin (1985): "Constructing a Control Group Using Multivariate Matched Sampling Methods that Incorporate the Propensity Score," The American Statistican, 39(1), 33-38.

Rosenbaum, P. R., and D. Rubin (1983): "The Central Role of the Propensity Score in Observational Studies for Causal Effects," Biometrika, 70(1), 41-50.

Schäfer, D., O. Talavera, and C. Weir (2011): "Entrepreneurship, Windfall Gains and Financial Constraints: Evidence from Germany," Economic Modelling, 28(5), 21742180 .

Shane, S. (2003): A General Theory of Entrepreneurship: The Individual-Opportunity Nexus. Edward Elgar, Cheltenham (UK), Northhampton (MA, USA).

SiAnESI, B. (2004): "An Evaluation of the Swedish System of Active Labour Market Programmes in the 1990s," The Review of Economics and Statistics, 86(1), 133-155.

Storey, D. J. (2003): "Entrepreneurship, Small and Medium Sized Enterprises and Public Policies," in Handbook of Entrepreneurship Research, ed. by Z. Acs, and D. Audretsch, pp. 473-511. Kluwer Academic Publishers.

Tervo, H. (2006): "Regional Unemployment, Self-employment and Family Background," Applied Economics, 38, 1055-1062.

Tokila, A., M. Haapanen, and J. Ritsilä (2008): "Evaluation of Investment Subsidies: When Is Deadweight Zero?," International Review of Applied Economics, 22(5), 585600 . 
Ucbasaran, D., P. Westhead, and M. Wright (2008): "Opportunity Identification and Pursuit: Does an Entrepreneur's Human Capital Matter?," Small Business Economics, 30, 153-173.

van PraAg, M., J. van Sluis, and W. Vijverberg (2008): "Education and Entrepreneurship Selection and Performance: A Review of the Empirical Literature," Journal of Economic Surveys, 22, 795-841.

Whiteford, P., and W. Adema (2007): "What Works Best in Reducing Child Poverty: A Benefit or Work Strategy?," Social, Employment and Migration Working Papers 51, OECD. 


\section{Tables and Figures}

Figure 1: Start-up Activity in Germany 2006-2011

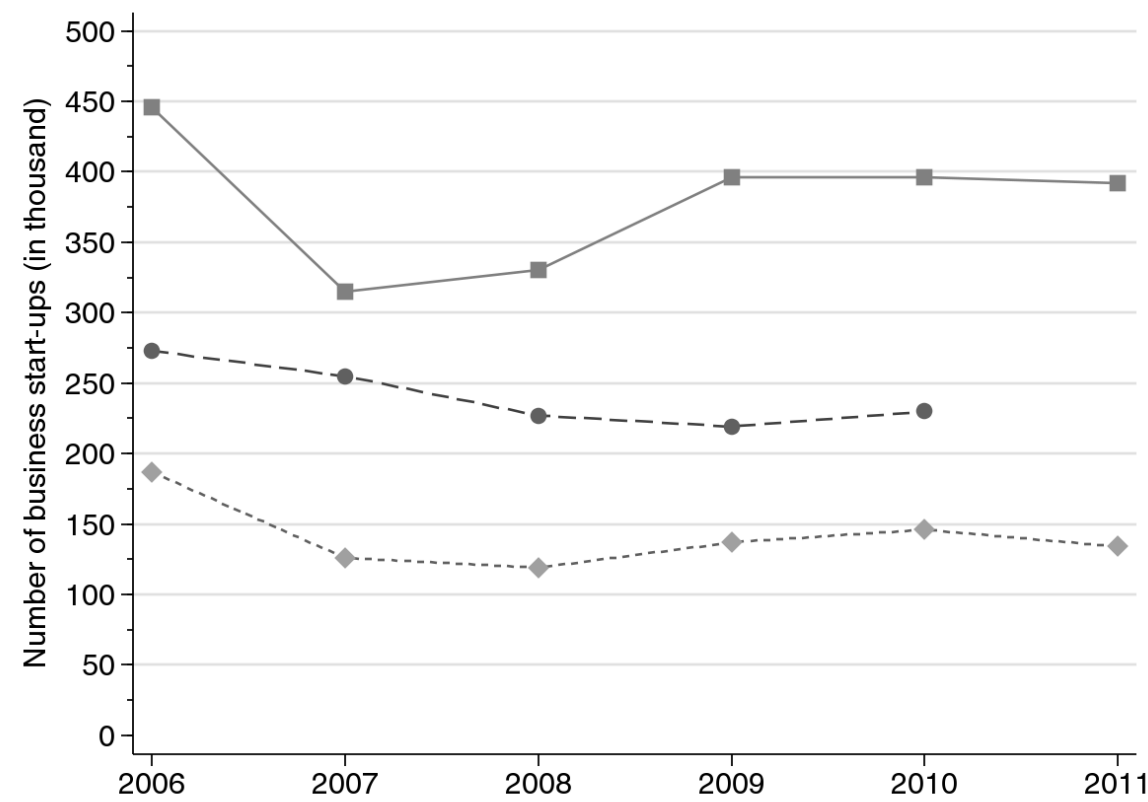

---- Microcensus (Source: Piorkowsky and Buddensiek, 2011)

$\longrightarrow \quad$ KfW Start-up Monitor (Source: Kreditanstalt für Wiederaufbau, 2012)

$\cdots$ Start-up Subsidy (Source: Statistics of the Federal Employment Agency)

Notes: Only full-time business start-ups. 
Figure 2: Data Creation

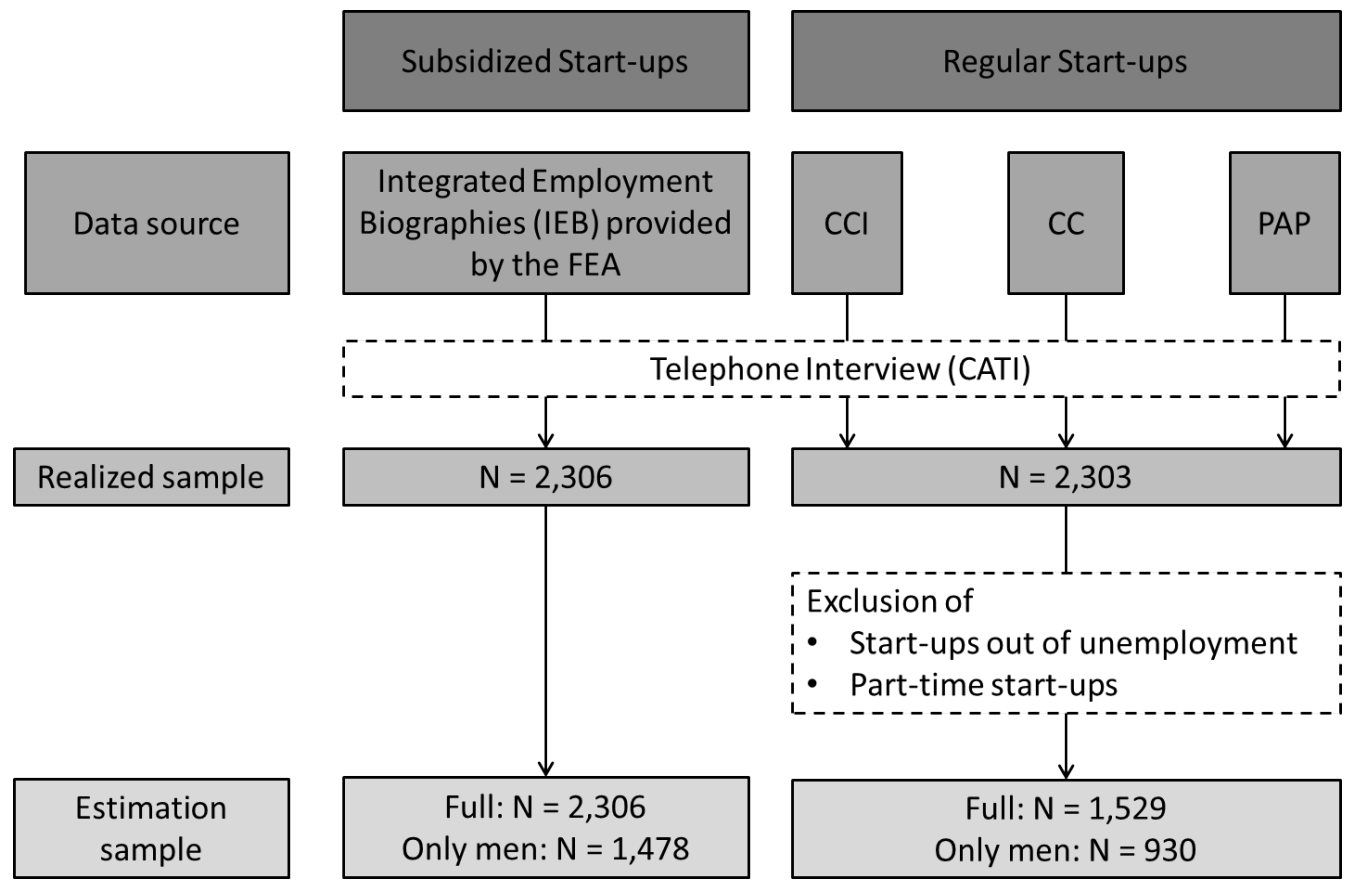


Table 1: Comparison of the Realized Sample of Non-Subsidized Business Founders with a Representative Sample of All Business Founders Based on the German Microcensus

\begin{tabular}{lcc}
\hline \hline & $\begin{array}{c}\text { Realized sample of } \\
\text { non-subsidized } \\
\text { business founders }\end{array}$ & $\begin{array}{c}\text { All business founders } \\
\text { based on the } \\
\text { German Microcensus }\end{array}$ \\
\hline Men & 63.4 & $57.0^{* * *}$ \\
East Germany & 10.5 & $21.4^{* * *}$ \\
Not German & 5.3 & $13.8^{* * *}$ \\
Age distribution & & \\
$<25$ & 4.5 & $8.7^{* * *}$ \\
$25-<35$ & 21.0 & $30.0^{* * *}$ \\
35 - <45 & 29.4 & $32.6^{*}$ \\
$45-<56$ & 29.3 & $21.5^{* * *}$ \\
$\geq 56$ & 15.9 & $7.2^{* * *}$ \\
Professional Education & & $16.0^{* * *}$ \\
Unskilled workers & 5.4 & 48.1 \\
Skilled workers (apprenticeship) & 47.6 & $9.7^{* * *}$ \\
Technical college education (master craftsman) & 20.3 & $26.0^{* *}$ \\
University education & 22.6 & $0.1^{* * *}$ \\
Others & 4.1 & 1.2 \\
Sector Business was founded in & & $6.7^{* * *}$ \\
Agriculture, forestry, fishing & 1.8 & 8.7 \\
Manufacturing, crafts & 21.8 & $13.6^{* * *}$ \\
Construction & 7.4 & $3.2^{*}$ \\
Retail & 18.1 & 4.0 \\
Logistics and transport services & 2.0 & 4.8 \\
Financial and insurance services & 2.9 & $50.2^{* * *}$ \\
Information technology & 4.9 & $7.7^{* * *}$ \\
Other services & 26.5 & 1,053 \\
Other sectors & 14.7 & \\
\hline Number of observations & 2,303 & \\
\hline \hline & & \\
\hline Notes Alt & & \\
\hline
\end{tabular}

Notes: All numbers are percentages. The information from the German Microcensus is based on own calculations using the scientific-use-file of the 2009 survey, including all individuals who reported that they became self-employed in $2009(\mathrm{~N}=1,053)$. Based on a t-test with unequal variances, statistical significance at the $1 / 5 / 10 \%$-level is denoted by $* * * / * * / *$. 
Table 2: Individual and Business Related Characteristics of Subsidized and Regular Startups at the Time of Start-up

\begin{tabular}{|c|c|c|}
\hline & $\begin{array}{l}\text { Subsidized } \\
\text { founders }\end{array}$ & $\begin{array}{l}\text { Regular } \\
\text { founders }\end{array}$ \\
\hline \multicolumn{3}{|l|}{ Motivation to start a business } \\
\hline Wanted to be my own boss & 70.1 & 68.2 \\
\hline I wanted to earn more money & 58.7 & 57.5 \\
\hline Advice by external institution (e.g. Employment Agency) & 18.9 & $11.7^{* * *}$ \\
\hline No employment alternative & 36.8 & $17.6^{* * *}$ \\
\hline \multicolumn{3}{|l|}{ School achievement } \\
\hline None or lower secondary school & 21.0 & 21.6 \\
\hline Middle secondary school & 31.3 & 31.6 \\
\hline Upper secondary school & 47.8 & 46.8 \\
\hline \multicolumn{3}{|l|}{ Professional education } \\
\hline Unskilled workers & 4.8 & 6.2 \\
\hline Skilled Workers (apprenticeship) & 45.9 & $36.1^{* * *}$ \\
\hline Technical college education (master craftsman) & 17.1 & $24.9^{* * *}$ \\
\hline University education & 30.9 & $27.6^{*}$ \\
\hline Others & 1.4 & $5.1^{* * *}$ \\
\hline \multicolumn{3}{|c|}{ Employment experience before start-up (as a share of working time) ${ }^{b}$ ) } \\
\hline Lifetime Employment & 73.0 & $76.0^{* * *}$ \\
\hline Lifetime Unemployment & 4.6 & $2.0^{* * *}$ \\
\hline \multicolumn{3}{|l|}{ Industry-specific experience before start-up } \\
\hline Due to dependent employment & 71.7 & $61.3^{* * *}$ \\
\hline Due to previous self-employment & 19.4 & $24.6^{* * *}$ \\
\hline Due to secondary employment & 21.1 & $17.0^{* * *}$ \\
\hline Due to hobby & 25.0 & 27.3 \\
\hline Due to honorary office & 6.1 & 7.2 \\
\hline None & 11.0 & 12.4 \\
\hline \multicolumn{3}{|l|}{ Intergenerational transmission } \\
\hline Parents are/were self-employed & 32.9 & $46.6^{* * *}$ \\
\hline Takeover of parents' business & 2.8 & $14.4^{* * *}$ \\
\hline Capital invested at start-up (in \%) & 81.6 & 82.0 \\
\hline Average amount invested (in Euro) & $21,739.5$ & $44,172.3^{* * *}$ \\
\hline [Median] & {$[8,000.0]$} & {$[15,000.0]$} \\
\hline$[\mathrm{Max}]$ & {$[600,000.0]$} & {$[650,000.0]$} \\
\hline$[$ Share $\geq 50,000$ Euro] & {$[7.8]$} & {$[16.1]$} \\
\hline Share of equity (in \%) & 73.3 & 74.3 \\
\hline \multicolumn{3}{|l|}{ Raising of credit since start-up (in \%) } \\
\hline Yes, loan received & 20.0 & $28.9^{* * *}$ \\
\hline No, but wanted to borrow & 16.0 & $10.7^{* * *}$ \\
\hline No loan needed & 64.0 & $60.4^{*}$ \\
\hline \multicolumn{3}{|l|}{ Receipt of other subsidies/programs (in \%) } \\
\hline Promotional loan ${ }^{c)}$ & 28.0 & 33.5 \\
\hline Business coaching & 15.5 & $6.5^{* * *}$ \\
\hline Number of Observations & 1,478 & 930 \\
\hline
\end{tabular}

Notes: Subsidized founders: Out of unemployment. Regular founders: Non-subsidized business founders out of non-unemployment. All numbers are percentages and measured at start-up. Based on a t-test, statistical significance at the $1 / 5 / 10 \%$-level is denoted by $* * * / * * / *$.

a) Measured at the time of the interview, i.e., 20 months after start-up.

b) Shares are calculated by dividing the cumulative time spent in employment/unemployment in the past by the total time spent in the labor market (as approximated by age in years minus 15).

c) Only individuals who received a loan. 
Table 3: Business Development 19 Months After Start-up

\begin{tabular}{|c|c|c|c|}
\hline & $\begin{array}{c}\text { Subsidized } \\
\text { founders } \\
\text { (1) }\end{array}$ & $\begin{array}{l}\text { Regula } \\
\text { raw } \\
(2)\end{array}$ & $\begin{array}{l}\text { founders } \\
\text { conditional } \\
\qquad(3)\end{array}$ \\
\hline \multicolumn{4}{|l|}{ Full sample } \\
\hline \multicolumn{4}{|l|}{ Main labor market status (in \%) } \\
\hline Self-employed & 80.7 & $72.6^{* * *}$ & $74.4^{* *}$ \\
\hline Dependent employed & 11.5 & 10.6 & 14.7 \\
\hline Unemployed & 4.8 & $1.6^{* * *}$ & 4.2 \\
\hline Number of Observations & 1,449 & \multicolumn{2}{|c|}{930} \\
\hline \multicolumn{4}{|l|}{ Income measures (in Euro, net) ${ }^{a}$ ) } \\
\hline Monthly working income & $2,146.0$ & $2,636.6^{* * *}$ & $2,374.4$ \\
\hline Number of Observations & 1,301 & \multicolumn{2}{|c|}{785} \\
\hline \multicolumn{4}{|c|}{ Conditional analysis: Self-employed individuals only } \\
\hline \multicolumn{4}{|c|}{ Income measures (in Euro, net) ${ }^{a}$ ) } \\
\hline Monthly working income & $2,388.8$ & $3,243.9^{* * *}$ & $3,073.0^{* *}$ \\
\hline Hourly working income & 11.5 & $16.4^{* * *}$ & $15.1^{* *}$ \\
\hline Working time (in hours/week) & 51.3 & 51.1 & 51.5 \\
\hline Monthly equivalent household income ${ }^{b)}$ & $2,050.4$ & $2,792.3^{* * *}$ & $2,382.1^{*}$ \\
\hline Number of Observations & 967 & \multicolumn{2}{|c|}{517} \\
\hline \multicolumn{4}{|l|}{ Employee structure } \\
\hline At least one employee (in \%) & 36.1 & $62.8^{* * *}$ & $56.5^{* * *}$ \\
\hline Number of full-time equivalents ${ }^{c)}$ & 3.1 & $7.0^{* * *}$ & $6.2^{* * *}$ \\
\hline Number of Observations & 1,156 & \multicolumn{2}{|c|}{675} \\
\hline \multicolumn{4}{|l|}{ Innovation implemented by businesses (in \%) ${ }^{d)}$} \\
\hline Filed patent application & 2.0 & $5.0^{* *}$ & 2.6 \\
\hline Filed application to legally protect corporate identity & 6.8 & $12.8^{* * *}$ & $16.0^{* *}$ \\
\hline Number of Observations & 547 & \multicolumn{2}{|c|}{401} \\
\hline \multicolumn{4}{|c|}{$\begin{array}{l}\text { Note: Subsidized founders: Out of unemployment. Regular founders: Non-subsidized business founders } \\
\text { out of non-unemployment. The first column shows the outcome variables as realized by the subsidized } \\
\text { businesses } 19 \text { months after start-up. Column two and three show the raw and conditional values for regular } \\
\text { business founders respectively. Conditional values are calculated based on propensity score matching. } \\
\text { Statistical significance at the } 1 / 5 / 10 \% \text {-level is denoted by } * * * / * / * \text { and in case of the conditional values } \\
\text { are based on bootstrapping with } 200 \text { replications. Deviant absolute values of number of observations } \\
\text { compared to Table A.3 due to implemented common support conditions and missing observations in } \\
\text { outcome variables. } \\
\text { a) We excluded eight individuals who reported a monthly income larger than } 30,000 \text { Euro. } \\
\text { b) The equivalent income is calculated by adjusting the household income by the number of household } \\
\text { members. The household income is divided by the weighted number of household members. Following the } \\
\text { actual OECD equivalence scale, the household head achieves a weight of one, all children below the age } \\
\text { of } 15 \text { are weighted with } 0.3 \text { and everybody else with } 0.5 \text { (see Whiteford and Adema, 2007). } \\
\text { c) Number of full-time equivalent employees is a weighted sum of different employment types, whereby full- } \\
\text { time worker receive the weight } 1 \text {, part-time worker and apprentices a weight of } 0.5 \text {, and other employees } \\
\text { a weight of } 0.25 \text {. We excluded four observations with inconsistent information and one statistical outlier } \\
\text { from the analysis. } \\
\text { d) Only half of the sample (randomly drawn) received this question. }\end{array}$} \\
\hline
\end{tabular}


Table 4: Descriptive Evidence on the Occurrence of Deadweight Effects Related to the Start-up Subsidy

\begin{tabular}{lll}
\hline \hline $\begin{array}{c}\text { Second dimension of deadweight effects } \\
\text { Statement: The subsidy was highly relevant for business } \\
\text { survival during the founding period (first six months). }{ }^{a}\end{array}$ & Total \\
\cline { 1 - 2 } Disagree $\quad$ Perhaps Agree & \\
\hline
\end{tabular}

First dimension of deadweight effects

Statement 1: I would you have started a business even without the subsidy? ${ }^{a}$ )

$\begin{array}{llllc}\text { Disagree } & 5.4 & 3.2 & 33.7 & 42.3 \\ \text { Perhaps } & 2.0 & 0.9 & 6.5 & 9.4 \\ \text { Agree } & 21.3 & 4.7 & 22.3 & 48.3\end{array}$

Statement 2: Did you intentionally register as unemployed to receive the subsidy?

\begin{tabular}{lllll} 
No & 20.2 & 6.2 & 50.8 & 77.2 \\
Yes & 8.6 & 2.5 & 11.7 & 22.8 \\
\hline
\end{tabular}

Number of Observations

1,471

Notes: Values are measured 19 months after start-up. Only subsidized founders. Shares in \%.

a) The categories rely on an aggregation of a scale variable. The respondents were faced with the statement and asked to give their answer on a scale from 1 (fully disagree) to 7 (fully agree). We categorized the values 1 to 3 to "Disagree", 4 to "Perhaps", and 5 to 7 to "Agree". 
Table 5: Detailed Consideration of Business Development to Determine the Role of Deadweight Effects
Subgroup of subsidized founders that is potentially affected by deadweight effects

Full sample

\begin{tabular}{lcc} 
Share in self-employment (in \%) & 92.6 & $79.8^{* * *}$ \\
\hline Number of Observations & 122 & 930
\end{tabular}

\begin{tabular}{|c|c|c|}
\hline \\
\hline \multicolumn{3}{|c|}{ 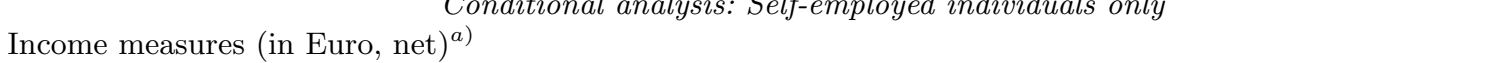 } \\
\hline Monthly working income & $3,415.9$ & $4,620.6^{*}$ \\
\hline Hourly working income & 16.0 & 22.4 \\
\hline Number of Observations & 103 & 517 \\
\hline \multicolumn{3}{|l|}{ Employee structure } \\
\hline At least one employee (in \%) & 46.9 & $72.3^{* * *}$ \\
\hline Number of full-time equivalents ${ }^{b)}$ & 3.2 & $6.8^{* * *}$ \\
\hline Number of Observations & 113 & 667 \\
\hline \multicolumn{3}{|l|}{ Innovation implemented by businesses (in $\%)^{c}$ ) } \\
\hline Filed patent application & 1.8 & 3.2 \\
\hline Filed application to legally protect corporate identity & 7.0 & $16.6^{*}$ \\
\hline Number of Observations & 57 & 398 \\
\hline
\end{tabular}

Note: Values are measured 19 months after start-up. The first column shows the outcome variables as realized by the subsidized businesses out of unemployment 19 months after start-up. Column two shows the conditional values for regular business founders. Conditional values are calculated based on propensity score matching. Statistical significance at the $1 / 5 / 10 \%$-level is denoted by $* * * / * * *$ and are based on bootstrapping with 200 replications.

a) We excluded eight individuals who reported a monthly income larger than 30,000 Euro.

b) Number of full-time equivalent employees is a weighted sum of different employment types, whereby full-time worker receive the weight 1 , part-time worker and apprentices a weight of 0.5 , and other employees a weight of 0.25 . We excluded four observations with inconsistent information and one statistical outlier from the analysis.

c) Only half of the sample (randomly drawn) received this question. 


\section{A Appendix}

\section{A.1 Additional Tables}

Table A.1: Comparison of the Realized Sample of Non-Subsidized Business Founders with a Representative Sample of All Business Founders Based on the German Microcensus Separated by Gender

\begin{tabular}{|c|c|c|c|c|}
\hline & \multicolumn{2}{|c|}{$\begin{array}{l}\text { Realized sample of } \\
\text { non-subsidized } \\
\text { business founders }\end{array}$} & \multicolumn{2}{|c|}{$\begin{array}{l}\text { All business founders } \\
\text { based on the } \\
\text { German Microcensus }\end{array}$} \\
\hline & Men & Women & Men & Women \\
\hline East Germany & 11.2 & 9.3 & $20.5^{* * *}$ & $22.5^{* * *}$ \\
\hline Not German & 4.9 & 5.9 & $15.5^{* * *}$ & $11.5^{* * *}$ \\
\hline Started self-employment as first activity and in full-time & 63.7 & 71.1 & $81.5^{* * *}$ & $53.4^{* * *}$ \\
\hline \multicolumn{5}{|l|}{ Age distribution } \\
\hline$<25$ & 4.9 & 3.9 & $8.5^{* * *}$ & $9.1^{* * *}$ \\
\hline $25-<35$ & 22.5 & 18.3 & $30.8^{* * *}$ & $28.9^{* * *}$ \\
\hline $35-<45$ & 28.1 & 31.6 & $31.8^{*}$ & 33.6 \\
\hline $45-<56$ & 26.2 & 34.5 & $21.0^{* *}$ & $22.1^{* * *}$ \\
\hline$\geq 56$ & 18.3 & 11.7 & $7.8^{* * *}$ & $6.4^{* * *}$ \\
\hline \multicolumn{5}{|l|}{ Professional Education } \\
\hline Unskilled workers & 4.9 & 6.3 & $17.7^{* * *}$ & $13.9^{* * *}$ \\
\hline Skilled workers (apprenticeship) & 40.9 & 59.3 & $47.7^{* * *}$ & $48.8^{* * *}$ \\
\hline Technical college education (master craftsman) & 25.3 & 11.5 & $9.8^{* * *}$ & 9.5 \\
\hline University education & 24.9 & 18.5 & 24.7 & $27.8^{* * *}$ \\
\hline Others & 3.9 & 4.4 & $1.7^{* * *}$ & $0.0^{* * *}$ \\
\hline \multicolumn{5}{|l|}{ Sector Business was founded in } \\
\hline Agriculture, forestry, fishing, animal breeding & 2.4 & 0.7 & 1.5 & 0.9 \\
\hline Crafts, manufacturing, car repair, gardening & 23.2 & 19.1 & $9.0^{* * *}$ & $3.3^{* * *}$ \\
\hline Construction & 10.3 & 2.4 & $14.8^{* * *}$ & $0.7^{* *}$ \\
\hline Retail & 15.4 & 22.8 & $12.3^{*}$ & $15.2^{* * *}$ \\
\hline Transport, information, logistics, courier service & 2.4 & 1.4 & $4.2^{* *}$ & 2.0 \\
\hline Financial service, insurance industry & 3.4 & 2.0 & $5.0^{*}$ & 2.7 \\
\hline IT, data processing & 7.0 & 1.3 & 7.0 & 1.8 \\
\hline Other services & 21.6 & 35.1 & $42.8^{* * *}$ & $60.0^{* * *}$ \\
\hline Other sectors & 14.4 & 15.2 & $3.3^{* * *}$ & 13.5 \\
\hline Number of observations & 1,460 & 843 & 600 & 453 \\
\hline
\end{tabular}

Notes: All numbers are percentages. The information from the German Microcensus is based on own calculations using the scientific-use-file of the 2009 survey, and includes all male individuals who reported to have become selfemployed in 2009. Based on a t-test with unequal variances, statistical significance compared with non-subsidized founders is denoted by $* * * / * * / *$ at the $1 / 5 / 10 \%$-level. 
Table A.2: Selected Descriptive Statistics

\begin{tabular}{|c|c|c|c|}
\hline & $\begin{array}{l}\text { Subsidized } \\
\text { founders }\end{array}$ & $\begin{array}{l}\text { Regular } \\
\text { founders }\end{array}$ & p-value \\
\hline Number of observation & 1,478 & 930 & \\
\hline \multicolumn{4}{|l|}{ Personal characteristics } \\
\hline East Germany & 21.7 & 10.9 & 0.000 \\
\hline \multicolumn{4}{|l|}{ Age distribution } \\
\hline$<25$ & 3.1 & 6.0 & 0.001 \\
\hline $25-<35$ & 24.3 & 20.5 & 0.033 \\
\hline $35-<45$ & 32.5 & 26.9 & 0.004 \\
\hline $45-<56$ & 28.1 & 24.2 & 0.036 \\
\hline$\geq 56$ & 12.0 & 22.4 & 0.000 \\
\hline Children under six years in household & 20.6 & 15.4 & 0.001 \\
\hline Children between six and 14 years in household & 23.0 & 21.4 & 0.357 \\
\hline Married & 57.2 & 61.1 & 0.058 \\
\hline Not German & 6.7 & 4.9 & 0.079 \\
\hline \multicolumn{4}{|l|}{ Human capital } \\
\hline \multicolumn{4}{|l|}{ School achievement } \\
\hline None or lower secondary school & 21.0 & 21.6 & 0.709 \\
\hline Middle secondary school & 31.3 & 31.6 & 0.855 \\
\hline Upper secondary school & 47.8 & 46.8 & 0.635 \\
\hline \multicolumn{4}{|l|}{ Professional education } \\
\hline Skilled workers (apprenticeship) & 45.9 & 36.1 & 0.000 \\
\hline Technical college education (master craftsman) & 17.1 & 24.9 & 0.000 \\
\hline University education & 30.9 & 27.6 & 0.086 \\
\hline Unskilled workers/others & 6.2 & 11.3 & 0.000 \\
\hline \multicolumn{4}{|l|}{ Intergenerational transmission } \\
\hline Parents are/were self-employed & 32.9 & 46.6 & 0.000 \\
\hline Business takeover from parents & 2.8 & 14.4 & 0.000 \\
\hline Parents born abroad & 20.4 & 15.9 & 0.006 \\
\hline \multicolumn{4}{|l|}{ School achievement of father } \\
\hline None or lower secondary school & 55.5 & 58.4 & 0.171 \\
\hline Middle secondary school & 18.2 & 17.4 & 0.627 \\
\hline Upper secondary school & 24.8 & 23.8 & 0.553 \\
\hline Father unknown & 1.4 & 0.4 & 0.020 \\
\hline Father of respondent employed at age 15 & 0.873 & 0.875 & 0.897 \\
\hline \multicolumn{4}{|c|}{ Labor market history } \\
\hline \multicolumn{4}{|c|}{ Monthly net income from last dependent employment right before start-up } \\
\hline Dependently employed and income not specified & 3.8 & 7.2 & 0.000 \\
\hline $0-1,000$ Euro & 9.4 & 4.8 & 0.000 \\
\hline$>1,000-1,500$ Euro & 25.3 & 14.3 & 0.000 \\
\hline$>1,500-2,500$ Euro & 32.1 & 21.8 & 0.000 \\
\hline$>2,500$ Euro & 21.4 & 15.9 & 0.001 \\
\hline In apprenticeship or marginal employment & 4.4 & 14.4 & 0.000 \\
\hline In other status & 3.6 & 21.5 & 0.000 \\
\hline \multicolumn{4}{|c|}{ Duration of dependent employment right before start-up } \\
\hline$<1$ year & 6.7 & 2.9 & 0.000 \\
\hline 5 or more years & 54.8 & 49.8 & 0.016 \\
\hline
\end{tabular}


Table A.2 continued. $\begin{array}{ccc}\begin{array}{c}\text { Subsidized } \\ \text { founders }\end{array} & \begin{array}{c}\text { Regular } \\ \text { founders }\end{array}\end{array}$

Unemployment experience before start-up (as share of working time, stand. by age-15)

Not specified

$\begin{array}{rrr}1.8 & 0.6 & 0.015 \\ 5.3 & 53.5 & 0.000 \\ 33.3 & 23.5 & 0.000 \\ 30.3 & 12.0 & 0.000 \\ 25.0 & 8.0 & 0.000 \\ 4.3 & 2.3 & 0.009\end{array}$

$>0-\leq 2$

$>2-\leq 5$

$>5-\leq 15$

$2.3 \quad 0.009$

Employment experience before start-up (as share of working time, stand. by age-15)

Not specified

$\begin{array}{lll}0.9 & 1.0 & 0.960\end{array}$

$\leq 50$

$\begin{array}{lll}16.4 & 14.6 & 0.233\end{array}$

$>50-\leq 70$

$21.4 \quad 16.5$

0.233

$>70-\leq 90$

$37.9 \quad 34.7$

0.118

$>90-\leq 99$

17.3

21.9

0.005

$>99$

6.0

11.3

0.000

Regional information

Federal state (selected states)

Baden-Wuerttemberg

Bavaria

$\begin{array}{lll}12.4 & 15.3 & 0.049\end{array}$

Saxony

$16.8 \quad 24.4 \quad 0.000$

Local macroeconomic conditions

Vacancies related to stock of unemployed

$5.5 \quad 4.7$

0.381

Unemployment rate

$\begin{array}{lll}15.0 & 15.4 & 0.215\end{array}$

Real GDP per capita in 2008 (in thousand Euro)

$8.6 \quad 7.5$

0.000

35.7

32.5

0.000

Business related characteristics

Sectoral distribution of business foundation

Agriculture, forestry, fishing

$\begin{array}{lll}0.9 & 2.3 & 0.005\end{array}$

Manufacturing, Crafts

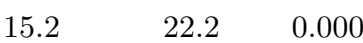

Construction

11.2

$9.9 \quad 0.325$

Retail

$14.0 \quad 16.0$

0.325
0.175

Transport, logistics

$\begin{array}{lll}4.9 & 2.5 & 0.003\end{array}$

Financial service, insurance industry

$5.8 \quad 3.9$

0.034

IT

0.183

Other services

Other sectors

$\begin{array}{lll}19.1 & 14.7 & 0.006\end{array}$

Industry-specific experience before start-up

Due to dependent employment

$\begin{array}{lll}71.7 & 61.3 & 0.000\end{array}$

Due to former self-employment

$\begin{array}{lll}71.4 & 24.6 \quad 0.002\end{array}$

Due to secondary employment

Due to hobby

Due to honorary office

None

$6.1 \quad 7.2$

0.281

$\begin{array}{lll}11.0 & 12.4 & 0.293\end{array}$

Capital invested at start-up

None

$\begin{array}{rrr}17.9 & 17.3 & 0.699 \\ 4.4 & 8.7 & 0.000\end{array}$

$<1,000$ Euro

$\begin{array}{ll}4.4 & 8.7\end{array}$

$1,000-<5,000$ Euro

$19.8 \quad 12.4$

0.000

$5,000-<1,000$ Euro

$16.1 \quad 8.5$

0.000

$10,000-<50,000$ Euro

31.7

32.9

$\geq 50,000$ Euro

$7.8 \quad 16.1$

0.549

Share of equity

45.9

47.2

Note: Subsidized founders: Out of unemployment. Regular founders: Non-subsidized business founders out of non-unemployment. All numbers are percentages (unless stated otherwise) and measured at start-up. P-value is based on a t-test on equal means. 


\section{A.2 Details on the Implementation of the Matching Procedure}

This section contains details on the implementation of the propensity score matching in order to align the group of regular business founders towards the group of subsidized start-ups in terms of observable characteristics. First of all, we estimate the propensity score $P(D=1 \mid X)$ to start a business out of unemployment and therefore receive the subsidy using probit-models. Table A.3 shows the results of the probit-estimation. We observe that particularly age, professional education, industry-specific experiences, labor market history, intergenerational transmission, regional characteristics and capital investment decisions at start-up significantly influence the probability of starting a business out of unemployment with subsidy receipt. In addition, Figure A.1 shows the distribution of the estimated propensity scores. Although the estimated propensity scores of subsidized business founders overlap the region of estimated scores for regular business founders to a large extent, there is only limited overlap in the tails of the distribution. To ensure that we only compare subsidized business founders to regular business founders with similar values of the propensity score, we exclude 29 subsidized business founders that have propensity score values above (below) the maximum (minimum) value of the regular business founders.

To finally align the group of regular business founders towards the group of subsidized start-ups, we apply a kernel matching. In fact, we apply an Epanechnikov Kernel with a bandwidth of 0.06 . This offers the advantage of increasing efficiency by using the full set of regular business founders to construct the individual counterfactual outcome of previously unemployed business founders. Moreover, Kernel matching allows us to use bootstrapping in order to calculate standard errors and draw statistical inference. In this study, we use 200 replications to calculate standard errors (as suggested by Efron and R. J, 1993). Table A.4 shows different measures to assess the quality of the applied matching procedure, i.e. whether the matching successfully balances the distribution of observable characteristics between both groups. ${ }^{25}$ Based on a simple t-test, it can be seen that the number of variables with significant differences in sample means between the subsidized and regular founders significantly declines after matching. As results from the t-test allow for an assessment in terms of bias reduction in the marginal distribution of observable characteristics, we additionally provide the mean standardized bias (MSB) as suggested by Rosenbaum and Rubin (1985). We observe that the MSB is $16 \%$ before matching, whereas our matching procedure significantly reduces the respective MSB down to $4 \%$. This is below the suggested threshold of 3-5\% by Caliendo and Kopeinig (2008) and therefore indicates a successful matching. In a final step, we also re-estimate the propensity score using the matched sample and compare it to the initial propensity score estimation. Given that the matching is able to balance the samples of subsidized and regular founders, we would expect a sizeable reduction in the Pseudo- $\mathrm{R}^{2}$ between both regressions (Sianesi,

\footnotetext{
${ }^{25}$ See Caliendo and Kopeinig (2008) for a detailed discussion on the assessment of the matching quality and for an explanation of applied measures.
} 
2004). Indeed, this is confirmed by Table A.4, showing very low Pseudo- $\mathrm{R}^{2}$ for the matched sample estimation. Finally, we conclude that the applied matching procedure significantly reduces differences in observable characteristics between subsidized and regular business founders.

Figure A.1: Propensity Score Distributions — Subsidized Business Founders vs. Regular Business Founders

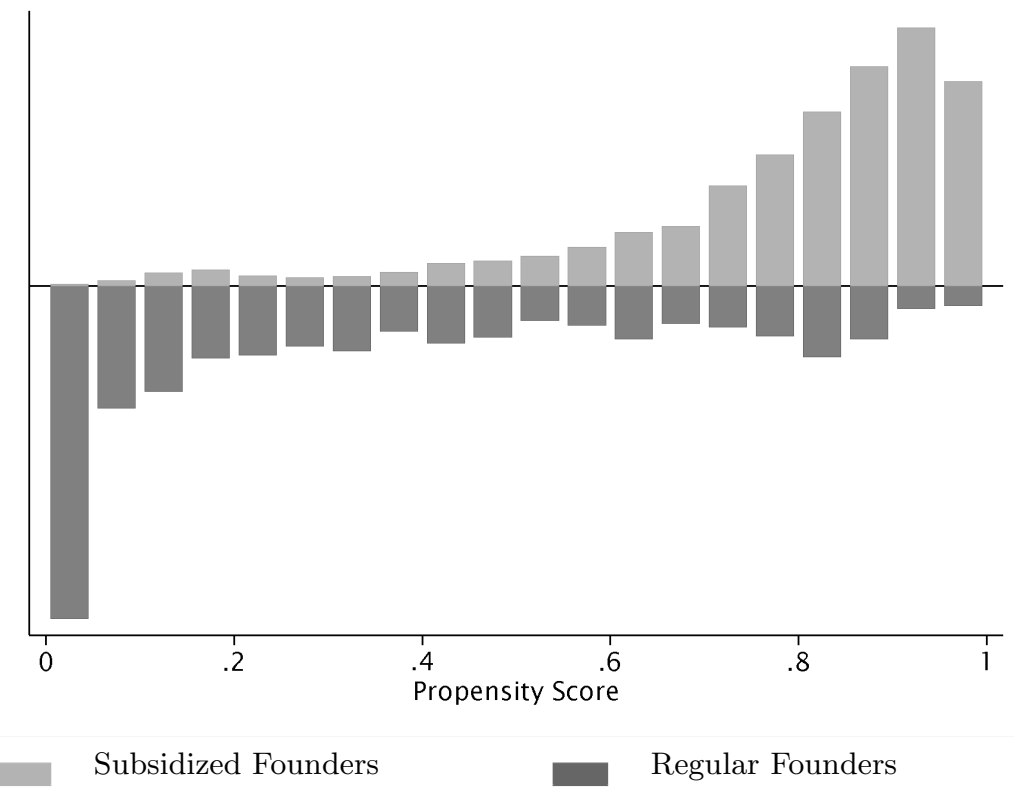

Note: Depicted are distributions of estimated propensity scores for subsidized business founders out of unemployment and regular business founders (i.e. nonsubsidized business founders out of non-unemployment) based on probit estimations as shown in Table A.3. 
Table A.3: Propensity Score Estimation — Subsidized Business Founders vs. Regular Business Founders

Dependent variable: Subsidized founders (1) vs. Regular Founders (0)

\begin{tabular}{lc}
\hline Personal characteristics & \\
East Germany & 0.238 \\
& $(0.174)$ \\
Age distribution (Ref.: $<25)$ & -.233 \\
$25-<35$ & $(0.192)$ \\
& -.186 \\
$35-<45$ & $(0.201)$ \\
$45-<56$ & -.169 \\
$\geq 56$ & $(0.208)$ \\
& $-.557^{* *}$ \\
Children under six years in household & $(0.221)$ \\
& 0.105 \\
Children between six and 14 years in household & $(0.094)$ \\
& 0.002 \\
Married & $(0.087)$ \\
Not German & -.022 \\
& $(0.08)$ \\
& -.078 \\
& $(0.152)$
\end{tabular}

\section{Human capital}

School achievement (Ref.: None or lower secondary school)

Middle secondary school

$-.072$

$(0.097)$

Upper secondary school

Professional education (Ref.: Unskilled workers/others) Skilled workers (apprenticeship)

$(0.113)$

Technical college education (master craftsman)

$0.435^{* * *}$

$(0.13)$

$0.26^{*}$

$(0.145)$

University education

$0.492^{* * *}$

(0.143)

Intergenerational transmission

Parents born abroad

Parents were/are self-employed

Highest Schooling Certificate of father (Ref.: No cert, Lower Secondary School) Middle Secondary School 0.053

(0.092)

Tertiary Education Certificate

0.105

(0.089)

Father unknown

$0.899^{* *}$

(0.392)

Business take-over from parents

$-.777^{* * *}$

$(0.15)$

Father of respondent employed at age 15

$0.235^{* *}$

(0.099)

Table continued. 
Table A.3 continued.

Dependent variable: Subsidized founders (1) vs. Regular Founders (0)

Labor market history

Monthly net income from last dependent employment right before start-up (Ref.: Dependently employed and income not specified)
0-1,000 Euro
$0.677^{* * *}$
$>1,000-1,500$ Euro
$(0.191)$
$1,500-25,00$ Euro
$(0.16)$
$>1,500-25,00$ Euro
$0.54^{* * *}$
$>2,500$ Euro
$(0.153)$
$0.557^{* * *}$
$(0.16)$
In Apprenticeship or Marginal Employment
$-.611^{* * *}$
$(0.2)$
In other Status
$-.663^{* * *}$
$(0.19)$
Duration of dependent employment right before start-up
$<1$ year
$-.162$
5 or more years
$(0.161)$
$-.210^{* *}$
$(0.092)$

Unemployment experience before start-up as share of working time $\left.{ }^{a}\right)($ Ref.: 0$)$ Not Specified

$2.006^{* * *}$

(0.33)

$>0-\leq 2$

$1.462^{* * *}$

$>2-\leq 5$

(0.093)

$>5-\leq 15$

$1.772^{* * *}$

$(0.103)$

$1.897^{* * *}$

$>15$

(0.116)

$1.607^{* * *}$

(0.19)

Employment experience before start-up as share of working time $\left.{ }^{a}\right)($ Ref.: $\leq 50)$

Not Specified

$-.360$

(0.359)

$>50-\leq 70$

$-.135$

(0.123)

$>70-\leq 90$

$-.128$

$>90-\leq 99$

$(0.12)$

$-.122$

(0.143)

$>99$

$-.295^{*}$

$(0.166)$

Regional information

Federal state (selected states)

Baden-Wuerttemberg

$-.164$

(0.125)

Bavaria

$-.210^{*}$

(0.108)

Saxony

$-.345^{* *}$

(0.174)

Local macroeconomic conditions

Relation of open vacancies to amount of unemployed $0.013^{* *}$

$(0.006)$

Average Unemployment Rate

0.022

$(0.021)$

Real GDP per capita in 2008 (in 1,000 Euro)

$0.01^{* * *}$

(0.003) 
Table A.3 continued.

Dependent variable: Subsidized founders (1) vs. Regular Founders (0)

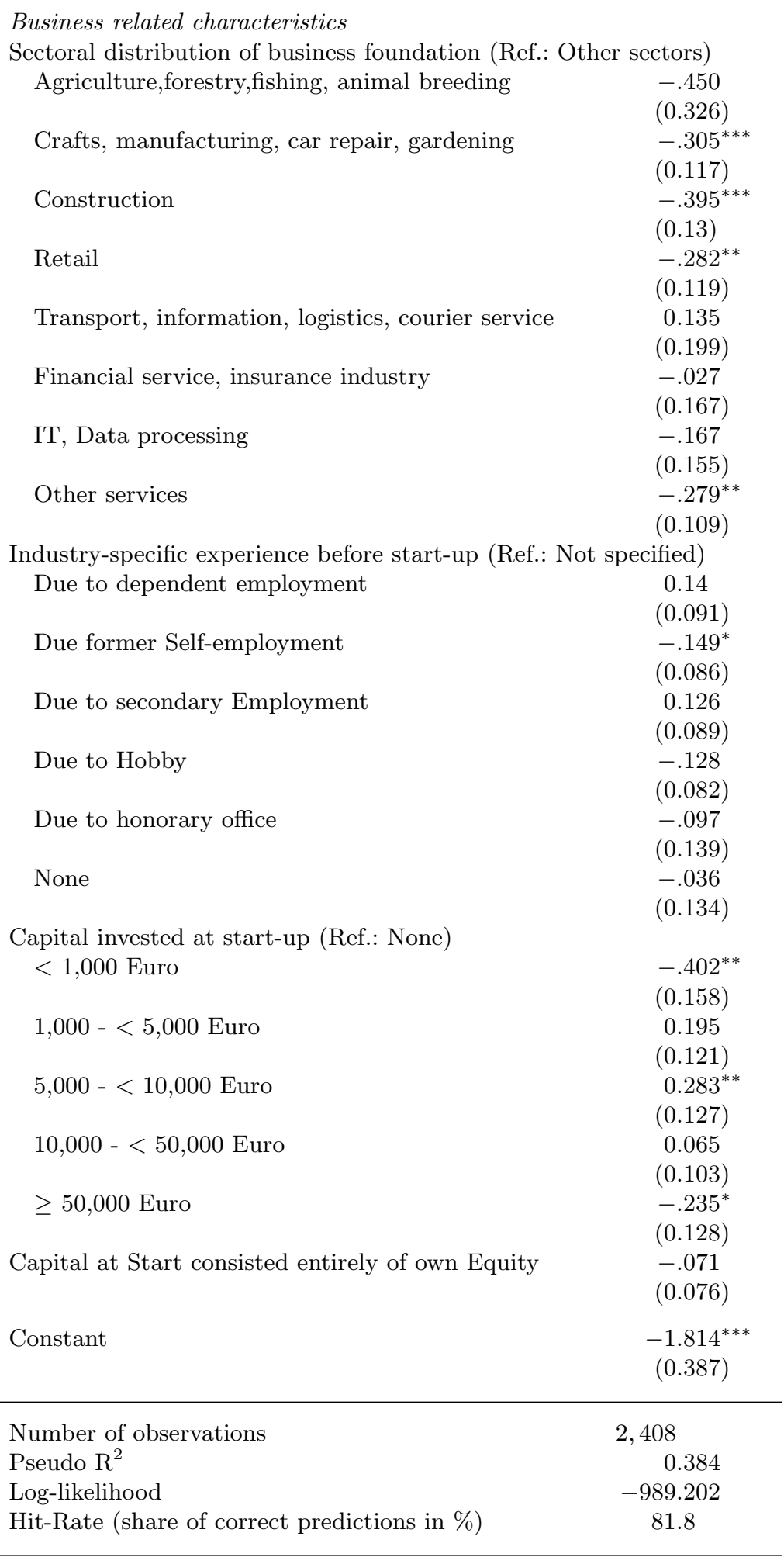

Notes: Subsidized founders: Out of unemployment. Regular founders: Nonsubsidized business founders out of non-unemployment. Standard errors in parentheses; statistical significance at the $1 / 5 / 10 \%$-level is denoted by $* * * / * * / *$.

a) Standardized by (Age-15) 
Table A.4: Matching Quality — Subsidized Business Founders vs. Regular Business Founders

Before Matching After Matching

$\begin{array}{lcc}\text { t-test of equal means }^{a} & & \\ \text { 1\%-level } & 40 & 4 \\ 5 \% \text {-level } & 48 & 17 \\ \text { 10\%-level } & 51 & 21 \\ \text { Mean standardized bias } & 15.76 & 4.12 \\ \text { Number of Variables with standardized bias of certain amount } & & \\ <1 \% & 3 & 26 \\ 1 \% \text { until }<3 \% & 7 & 12 \\ 3 \% \text { until }<5 \% & 6 & 24 \\ 5 \% \text { until }<10 \% & 14 & 3 \\ \geq 10 \% & 44 & 0.03 \\ \text { Pseudo } \mathrm{R}^{2} & & \end{array}$

\footnotetext{
Notes: Depicted are different statistics to assess the quality of the matching process, i.e., whether the distribution of observable characteristics between subsidized business founders out of unemployment and regular business founders (i.e. non-subsidized business founders out of non-unemployment) is sufficiently balanced. In total, 74 variables are considered. Deviant values in terms of Pseudo $\mathrm{R}^{2}$ compared to Table A.3 are due to implemented common support conditions, i.e., due to excluded observations.

a) Depicted is the number of variables which differ significantly between treated and controls. The decision is based on a simple t-test of equal means.
} 